\title{
Excitability and Burst Generation of AVPV Kisspeptin Neurons Are Regulated by the Estrous Cycle Via Multiple Conductances Modulated by Estradiol Action ${ }^{1,2,3}$
}

\author{
Luhong Wang, ${ }^{1}$ [Dichard A. DeFazio, ${ }^{1}$ and Suzanne M. Moenter ${ }^{1,2,3}$
}

DOI:http://dx.doi.org/10.1523/ENEURO.0094-16.2016

${ }^{1}$ Department of Molecular and Integrative Physiology, University of Michigan, Ann Arbor, MI 48109, ${ }^{2}$ Department of Obstetrics and Gynecology, University of Michigan, Ann Arbor, Ml 48109, and ${ }^{3}$ Department of Internal Medicine, University of Michigan, Ann Arbor, MI 48109

\begin{abstract}
The preovulatory secretory surge of gonadotropin-releasing hormone $(\mathrm{GnRH})$ is crucial for fertility and is regulated by a switch of estradiol feedback action from negative to positive. GnRH neurons likely receive estradiol feedback signals via $\mathrm{ER} \alpha$-expressing afferents. Kisspeptin neurons in anteroventral periventricular nucleus (AVPV) are thought to be critical for estradiol-positive feedback induction of the GnRH surge. We examined the electrophysiological properties of GFP-identified AVPV kisspeptin neurons in brain slices from mice on the afternoon of diestrus (negative feedback) and proestrus (positive feedback, time of surge). Extracellular recordings revealed increased firing frequency and action potential bursts on proestrus versus diestrus. Whole-cell recordings were used to study the intrinsic mechanisms of bursting. Upon depolarization, AVPV kisspeptin neurons exhibited tonic firing or depolarization-induced bursts (DIB). Both tonic and DIB cells exhibited bursts induced by rebound from hyperpolarization. DIB occurred similarly on both cycle stages, but rebound bursts were observed more often on proestrus. DIB and rebound bursts were both sensitive to $\mathrm{Ni}^{2+}$, suggesting that T-type $\mathrm{Ca}^{2+}$ currents $\left(I_{\mathrm{T}} \mathrm{s}\right)$ are involved. $I_{\mathrm{T}}$ current density was greater on proestrus versus diestrus. In addition to $I_{\mathrm{T}}$, persistent sodium current $\left(I_{\mathrm{NaP}}\right)$ facilitated rebound bursting. On diestrus, 4-aminopyridine-sensitive potassium currents contributed to reduced rebound bursts in both tonic and DIB cells. Manipulation of specific sex steroids suggests that estradiol induces the changes that enhance AVPV kisspeptin neuron excitability on proestrus. These observations indicate cycle-driven changes in circulating estradiol increased overall action potential generation and burst firing in AVPV kisspeptin neurons on proestrus versus diestrus by regulating multiple intrinsic currents.
\end{abstract}

Key words: burst; GnRH; Kisspeptin; persistent sodium current; steroid; T-type calcium current

\section{Significance Statement}

The brain controls fertility via the hypothalamo-pituitary-gonadal axis. Gonadotropin-releasing hormone $(\mathrm{GnRH})$ neurons form the final output pathway but are not directly sensitive to critical elements of gonadal steroid feedback. Kisspeptin neurons of the anteroventral periventricular nucleus may convey steroid feedback to $\mathrm{GnRH}$ neurons. We studied how action potential firing of kisspeptin neurons varies between two critical phases of the estrous cycle: diestrus when estradiol exerts negative feedback to suppress $\mathrm{GnRH}$ release; and proestrus when estradiol feedback activates $\mathrm{GnRH}$ neurons. Increased spontaneous and burst firing on proestrus was observed and attributable to estrous cycle-dependent changes in multiple ionic currents. These changes were specifically driven by estradiol. This estrous cycle regulation of kisspeptin neuron excitability is likely a critical aspect of female fertility. 


\section{Introduction}

Gonadotropin-releasing hormone $(\mathrm{GnRH})$ neurons form the final common pathway for central regulation of reproduction. GnRH stimulates the pituitary gland to secrete follicle-stimulating hormone and luteinizing hormone $(\mathrm{LH})$ to regulate gonadal functions. Gonadal steroids provide feedback to regulate $\mathrm{GnRH}$ release. In males and during most of the female reproductive cycle, sex steroids suppress $\mathrm{GnRH}$ neuron activity and release (Karsch et al., 1987; Moenter et al., 1990; Lubbers et al., 1998; Christian et al., 2005). In females, sustained elevations in estradiol levels during the follicular phase result in a switch of estradiol action from negative to positive feedback, inducing $\mathrm{GnRH}$ neuron activation, and a preovulatory surge of $\mathrm{GnRH}$ and LH release (Christian and Moenter, 2010). Although regulated by steroid feedback, $\mathrm{GnRH}$ neurons do not express detectable levels of most steroid receptors, including estrogen receptor $\alpha$ (ER $\alpha$; Hrabovszky et al., 2001), which mediates estradiol negative and positive feedback (Couse et al., 1999; Christian et al., 2008). Steroid-sensitive afferents thus likely transmit feedback signals to $\mathrm{GnRH}$ neurons. Estradiol-sensitive kisspeptinexpressing neurons in the arcuate nucleus and anteroventral periventricular nucleus (AVPV) may convey estradiolnegative and estradiol-positive feedback to $\mathrm{GnRH}$ neurons, respectively (Oakley et al., 2009).

Kisspeptin is a potent stimulator of $\mathrm{GnRH}$ neuron activity and release (Han et al., 2005; Pielecka-Fortuna et al., 2008; Glanowska et al., 2012). AVPV kisspeptin neurons express ER $\alpha$ (Smith et al., 2005), as well as GABA and glutamate (Cravo et al., 2011), both of which also excite GnRH neurons (DeFazio et al., 2002; Kuehl-Kovarik et al., 2002). AVPV kisspeptin neurons synapse on GnRH neurons (Kumar et al., 2015; Yip et al., 2015) and express elevated cFos levels during the $\mathrm{GnRH} / \mathrm{LH}$ surge (Smith et al., 2006). Infusion of anti-kisspeptin antibodies into the preoptic area (Kinoshita et al., 2005), or deletion of ER $\alpha$ specifically from kisspeptin neurons both block estradiolinduced LH surges (Dubois et al., 2015). Together, these observations suggest a role for AVPV kisspeptin neurons

Received April 25, 2016; accepted May 12, 2016; First published May 19, 2016.

${ }^{1}$ The authors declare no competing financial interests.

${ }^{2}$ Author contributions: L.W., R.A.D., and S.M.M. designed research; L.W. performed research; L.W., R.A.D., and S.M.M. analyzed data; R.A.D. contributed unpublished reagents/analytic tools; L.W. and S.M.M. wrote the paper.

${ }^{3}$ This research was supported by National Institute of Health/Eunice Kennedy Shriver National Institute of Child Health and Human Development Grant R01-HD-41469 to S.M.M.

Acknowledgments: We thank Elizabeth Wagenmaker and Laura Burger for expert technical assistance; and Caroline Adams, Laura Burger, Eden Dulka, Carol Elias, Kristen Ruka, Pei-San Tsai, and Elizabeth Wagenmaker for editorial comments. We also thank James L. Kenyon, University of Nevada, Reno, for the Excel spreadsheet used to calculate junction potentials.

Correspondence should be addressed to Suzanne M. Moenter, Department of Molecular and Integrative Physiology, University of Michigan, 7725 Med Sci II, 1137 E. Catherine Street, Ann Arbor, MI 48109. E-mail: smoenter@umich.edu. DOI:http://dx.doi.org/10.1523/ENEURO.0094-16.2016

Copyright (C) 2016 Wang et al.

This is an open-access article distributed under the terms of the Creative Commons Attribution 4.0 International, which permits unrestricted use, distribution and reproduction in any medium provided that the original work is properly attributed. in conveying estradiol-positive feedback to $\mathrm{GnRH}$ neurons.

Given the evidence for a role for AVPV kisspeptin neurons in estradiol-positive feedback, a fundamental question is how the firing activity of AVPV kisspeptin neurons shifts between estrous cycle stages to increase the release of kisspeptin, glutamate, and/or GABA during positive feedback. AVPV kisspeptin neurons express several ionic conductances that may shape firing patterns (Piet et al., 2013; Zhang et al., 2013b, 2015), some of which are regulated by the reproductive cycle (Piet et al., 2013), but the mechanisms that underlie changes in AVPV kisspeptin neuron excitability and the steroids underlying cycledependent shifts are not fully understood. In particular, the release of neuropeptides such as kisspeptin is classically linked with high-frequency bursts of action potentials (van den Pol, 2012).

We examined the spontaneous activity of AVPV kisspeptin neurons and the contributions of candidate currents to the firing properties of these cells during two estrous cycle stages: the afternoon of diestrus (di) representing estradiol negative feedback and the afternoon of proestrus (pro) representing positive feedback (Andrews et al., 1981; Gallo and Bona-Gallo, 1985). We then determined the specific circulating sex steroids that mediate the cycle-dependent changes in firing patterns and how different ionic conductances contribute to this.

\section{Material and Methods}

\section{Animals}

Kiss1-hrGFP mice (Cravo et al., 2011) were propagated in our colony. All mice were provided with water and Harlan 2916 chow ad libitum, and were held on a 14/10 h light/dark cycle with lights on at 4:00 A.M. Eastern Standard Time. Mice were used during the diestrous or proestrous phases of the estrous cycle determined by monitoring vaginal cytology of female mice 60-90 days old for at least a week before the experiments. Uterine mass was determined after brain slice preparation to confirm uteri on proestrus were $>100 \mathrm{mg}$, indicating exposure to endogenous high estradiol (Shim et al., 2000). To examine the role of specific sex steroids, similarly aged adult female mice were ovariectomized (OVX) under isoflurane anesthesia (Abbott Laboratories) and were either simultaneously implanted with a SILASTIC (Dow Corning) capsule containing $0.625 \mu \mathrm{g}$ of estradiol suspended in sesame oil (OVX+E) or not treated further (OVX). Bupivacaine was provided local to the incisions as an analgesic. These mice were studied 2-3 d after undergoing ovariectomy during the time of estradiol positive feedback (Christian et al., 2005). On the day of study, some OVX+E mice received a subcutaneous injection at 9:00 to 10:00 A.M. Eastern Standard Time of progesterone $(300 \mu \mathrm{g} / 20 \mathrm{~g}$; OVX+E+P; Dror et al., 2013), or sesame oil vehicle $(\mathrm{OVX}+\mathrm{E}+\mathrm{V})$. All mice were killed at 3:00 to 4:00 P.M. Eastern Standard Time. There were no differences observed between $\mathrm{OVX}+\mathrm{E}$ and $\mathrm{OVX}+\mathrm{E}+\mathrm{V}$ mice for firing patterns and burst generation; these data were combined for analyses, and only OVX $+\mathrm{E}$ mice were included for further studies to reduce animal use. All animal proce- 
dures were performed in accordance with the regulations of the University of Michigan animal care committee.

\section{Slice preparation and cell identification}

All chemicals were purchased from Sigma-Aldrich, unless noted. All solutions were bubbled with $95 \% \mathrm{O}_{2} / 5 \%$ $\mathrm{CO}_{2}$ throughout the experiments and for at least $30 \mathrm{~min}$ before exposure to tissue. The brain was rapidly removed and placed in ice-cold sucrose saline solution containing the following (in mM): 250 sucrose, $3.5 \mathrm{KCl}, 26 \mathrm{NaHCO}_{3}$, 10 D-glucose, $1.25 \mathrm{NaHPO}_{4}, 1.2 \mathrm{MgSO}_{4}$, and $3.8 \mathrm{MgCl}_{2}$, at $\mathrm{pH} 7.6$ and $345 \mathrm{mOsm}$. Coronal $(300 \mu \mathrm{m})$ slices were cut with a VT1200S Microtome (Leica Biosystems). Slices were incubated in a 1:1 mixture of sucrose saline and artificial CSF (ACSF) containing (in $\mathrm{mM}$ ) $135 \mathrm{NaCl}, 3.5 \mathrm{KCl}$, $26 \mathrm{NaHCO}_{3}, 10$ D-glucose, $1.25 \mathrm{Na}_{2} \mathrm{HPO}_{4}, 1.2 \mathrm{MgSO}_{4}$, and $2.5 \mathrm{CaCl}_{2}$, at $\mathrm{pH} 7.4$ and $305 \mathrm{mOsm}$, for $30 \mathrm{~min}$ at room temperature $\left(\sim 21\right.$ to $\left.23^{\circ} \mathrm{C}\right)$; and then were transferred to $100 \%$ ACSF for an additional $30-180 \mathrm{~min}$ at room temperature before recording. For recording, slices were placed into a chamber continuously perfused with ACSF at a rate of $3 \mathrm{ml} / \mathrm{min}$ with oxygenated ACSF heated to $31 \pm 1^{\circ} \mathrm{C}$ with an inline-heating unit (Warner Instruments). GFP-positive AVPV kisspeptin neurons were identified by brief illumination at $488 \mathrm{~nm}$ on an Olympus BX51WI microscope. Recorded cells were mapped to an atlas (Paxinos and Franklin, 2001) to determine whether any trends based on anatomical location emerged; no such trends were apparent in these datasets. Recordings were performed from 1 to $3 \mathrm{~h}$ after brain slice preparation. No more than three cells per animal were included for analysis of the same parameter, and at least five animals were tested per parameter.

\section{Electrophysiological recording}

Recording micropipettes were pulled from borosilicate capillary glass (type 7052, $1.65 \mathrm{~mm}$ outer diameter; 1.12 $\mathrm{mm}$ inner diameter; World Precision Instruments) using a Flaming/Brown P-97 puller (Sutter Instruments) to obtain pipettes with a resistance of 3-5 $\mathrm{M} \Omega$ for whole-cell recordings, and 2-3 M $\mathrm{M}$ for targeted extracellular recordings when filled with the appropriate pipette solution. Recording pipettes were wrapped with Parafilm to reduce capacitive transients. Recordings were made with an EPC-10 dual-patch clamp amplifier and Patchmaster software (HEKA Elektronik) running on a Macintosh computer.

\section{Extracellular recordings}

Targeted extracellular recordings were made to obtain the firing properties of cells under control conditions and with receptors for ionotropic $\mathrm{GABA}_{\mathrm{A}}$, and glutamate synaptic transmission antagonized with a combination of picrotoxin (100 $\mu \mathrm{M})$, aminophosphonovalerate (APV; 20 $\mu \mathrm{M})$, and 6-cyano-7-nitroquinoxaline-2,3-dione (CNQX; $10 \mu \mathrm{M})$. This method was used because it maintains internal milieu and has a minimal impact on the firing rate of neurons (Alcami et al., 2012). Recording pipettes were filled with HEPES-buffered solution containing (in mM) 150 $\mathrm{NaCl}, 10 \mathrm{HEPES}, 10$ glucose, $2.5 \mathrm{CaCl} 2,1.3 \mathrm{MgCl} 2$, and $3.5 \mathrm{KCl}$, at pH 7.4 and $310 \mathrm{mOsm}$, and low-resistance (22 $\pm 3 \mathrm{M} \Omega$ ) seals were formed between the pipette and neuron after first exposing the pipette to the slice tissue in the absence of positive pressure. Recordings were made in voltage-clamp mode with a $0 \mathrm{mV}$ pipette holding potential, and signals were acquired at $20 \mathrm{kHz}$ and filtered at $10 \mathrm{kHz}$. Resistance of the loose seal was checked frequently during first 3 min of recordings to ensure a stable baseline, and also before and after a 10 min recording period; data were not use if seal resistance changed $>30 \%$ or was $>25 \mathrm{M} \Omega$. The first $5 \mathrm{~min}$ of this $10 \mathrm{~min}$ recording were consistently stable among cells, and were thus used for analysis of firing rate and burst properties.

\section{Whole-cell recordings}

For whole-cell patch-clamp recording, two pipette solutions were used. Most recordings were performed with a physiologic pipette solution containing the following (in $\mathrm{mm}$ ): $135 \mathrm{~K}$ gluconate, $10 \mathrm{KCl}, 10$ HEPES, 5 EGTA, 0.1 $\mathrm{CaCl}_{2}, 4 \mathrm{MgATP}$, and $0.4 \mathrm{NaGTP}$, at $\mathrm{pH} 7.2$ with $\mathrm{NaOH}$ and $305 \mathrm{mOsm}$. A cesium-based pipette solution, in which cesium gluconate replaced potassium gluconate, was used to reduce potassium currents and allow better isolation of calcium currents. All potentials reported were corrected on-line for liquid junction potential of -15.7 or $-15.0 \mathrm{mV}$ for the physiologic or $\mathrm{Cs}^{+}$-based solution, respectively (Barry, 1994). For all whole-cell recordings, ACSF contained picrotoxin, APV, and CNQX, as detailed above.

After achieving a minimum $1.6 \mathrm{G} \Omega$ seal and the wholecell configuration, membrane potential was held at -70 $\mathrm{mV}$ between protocols during voltage-clamp recordings. Series resistance $\left(R_{s}\right)$, input resistance $\left(R_{\text {in }}\right)$, holding current $\left(I_{\text {hold }}\right)$, and membrane capacitance $\left(C_{m}\right)$ were frequently measured using a $5 \mathrm{mV}$ hyperpolarizing step from $-70 \mathrm{mV}$ (mean of 16 repeats, $20 \mathrm{~ms}$ duration). Only recordings with an $R_{\text {in }}$ of $>500 \mathrm{M} \Omega, I_{\text {hold }}$ of -40 to $10 \mathrm{pA}$, $R_{s}$ of $<20 M \Omega$, and a stable $C_{m}$ were used for analysis. $R_{s}$ was further evaluated for stability, and any voltage-clamp recordings with $\Delta R_{s}$ of $>15 \%$ before and after the recording protocols were excluded from analysis; current-clamp recordings with $\Delta R_{s}$ of $>20 \%$ were excluded. There was no difference in $I_{\text {hold }}, C_{m}$, or $R_{s}$ among any comparisons.

\section{Current-clamp recordings}

Depolarizing and hyperpolarizing current injections ( -50 to $+50 \mathrm{pA}$ for $500 \mathrm{~ms}$, in $5 \mathrm{pA}$ steps) were applied to cells from an initial voltage of $-71 \pm 2 \mathrm{mV}$, close to their basal membrane potential of $-68.8 \pm 1.9 \mathrm{mV}$ (DeFazio et al., 2014). In a small subset of experiments $(n=12)$, the initial voltage was adjusted to -65 and $-75 \mathrm{mV}$ to test the voltage dependence of depolarization-induced burstfiring patterns. Tetrodotoxin (TTX; $1 \mu \mathrm{M}$ ) was used to block action potentials and reveal underlying changes in membrane potential. $\mathrm{NiCl}_{2}(100 \mu \mathrm{M}), \mathrm{ZD} 7288(50 \mu \mathrm{M})$, and 4-aminopyridine (4-AP; $5 \mathrm{~mm}$ ) were applied to test the role of T-type calcium, hyperpolarization-activated mixed cation, and A-type potassium current conductance $\left(I_{A}\right)$ in generating bursts, respectively. 


\section{Voltage-clamp protocols for T-type $\mathrm{Ca}^{2+}$ current}

ACSF containing antagonists of ionotropic $\mathrm{GABA}_{\mathrm{A}}$ and glutamate receptors with TTX $(2 \mu \mathrm{M})$ and Cs-based internal solution were used for all recordings to isolate calcium currents. Two voltage protocols were used to isolate T-type $\mathrm{Ca}^{2+}$ currents $\left(I_{T}\right)$. First, total calcium current activation was examined. Inactivation was removed by hyperpolarizing the membrane potential to $-110 \mathrm{mV}$ for 350 $\mathrm{ms}$ (not shown in Fig. 4E). Next a $250 \mathrm{~ms}$ prepulse of $-110 \mathrm{mV}$ was given. Then membrane potential was varied in $10 \mathrm{mV}$ increments for $250 \mathrm{~ms}$ from -110 to -30 $\mathrm{mV}$. Finally, a test pulse of $-40 \mathrm{mV}$ for $250 \mathrm{~ms}$ was given. From examination of the current during the test pulse, it was evident that no sustained (high-voltage activated) calcium current was activated at potentials more hyperpolarized than $-40 \mathrm{mV}$. To remove high voltage-activated (HVA) contamination from the step to $-30 \mathrm{mV}$, a second protocol was used in which removal of inactivation $(-110$ $\mathrm{mV}, 350 \mathrm{~ms}$ ) was followed by a $250 \mathrm{~ms}$ prepulse at -40 $\mathrm{mV}$, then a step for $250 \mathrm{~ms}$ at $-30 \mathrm{mV}$, and finally a test pulse of $-40 \mathrm{mV}$ for $250 \mathrm{~ms}$. $I_{\mathrm{T}}$ was isolated by subtracting the trace following the $-40 \mathrm{mV}$ prepulse from those obtained after the $-110 \mathrm{mV}$ prepulse for the depolarized variable step to $-30 \mathrm{mV}$; raw traces from the initial voltage protocol were used without subtraction for variable steps from -110 to $-40 \mathrm{mV}$ because of the lack of observed activation of HVA at these potentials. Activation of $I_{\mathrm{T}}$ was assessed from the resulting family of traces by peak current during the variable step phase. Inactivation of $I_{T}$ was assessed from the peak current during the final $-40 \mathrm{mV}$ test pulse. For a subset of recordings $(n=3$ cells), $\mathrm{NiCl}_{2}(100 \mu \mathrm{M})$ was used to block current generated to confirm it was $I_{\mathrm{T}}$.

\section{Voltage-clamp ramp protocols for persistent sodium current}

Physiologic pipette solution was used for voltageclamp ramp recordings. A voltage ramp from -80 to -20 $\mathrm{mV}$ at $10 \mathrm{mV} / \mathrm{s}$ was used under control conditions and following TTX $(2 \mu \mathrm{M})$ application to characterize the voltage dependence and magnitude of a TTX-sensitive persistent sodium current $\left(I_{\mathrm{NaP}}\right)$. To test the relative roles of $I_{\mathrm{NaP}}$ and $\mathrm{I}_{\mathrm{A}}$ in cells that did not show rebound firing, current during the ramp was quantified under control conditions, then following $\mathrm{I}_{\mathrm{A}}$ block with 4-AP $(5 \mathrm{~mm})$ followed by the subsequent addition of TTX $(2 \mu \mathrm{M})$.

\section{Data analysis}

Data were analyzed off-line using custom software written in IgorPro version 6.31 (Wavemetrics) or MATLAB version 8.4 (MathWorks). For targeted extracellular recordings, the mean firing rate in hertz was determined over 5 min of stable recording. Parameters for the identification of bursts were chosen based on the distributions of interspike intervals and were confirmed by measuring the interspike interval of bursts that were identified manually using other criteria (upshift of baseline and progressive decrease of amplitude). Spikes were considered to form a burst if the interspike intervals were $<105 \mathrm{~ms}$. Spikes detected after an interval >105 ms were considered to be the start of a new burst or single spike. Bursts were automatically detected and confirmed by eye with false-positive detection errors manually corrected (Gaskins and Moenter, 2012).

Action potential parameters were quantified for the first action potential evoked in a firing train with minimal current injection (rheobase) from $-70 \mathrm{mV}$. First spike latency was the time from the onset of current injection to the peak of the first spike. The rate of rise was the maximal slope during the rising phase of the action potential. The action potential threshold was defined as the membrane potential at which the derivative exceeded $2 \mathrm{~V} / \mathrm{s}$. Fullwidth at half-maximum (FWHM) was the width of the spike at the half-maximal spike amplitude from threshold. The afterhyperpolarization (AHP) amplitude was the difference between the threshold and the most hyperpolarized potential after the spike. AHP time was the delay from threshold to the peak (most hyperpolarized) potential of the AHP.

In experiments examining $\mathrm{I}_{\mathrm{T}}$, the peak current amplitude at each step potential $(V)$ was first converted to conductance using the calculated reversal equilibrium potential of $\mathrm{Ca}^{2+}\left(E_{\mathrm{Ca}}\right)$ and $\mathrm{G}=\mathrm{I} /\left(E_{\mathrm{Ca}}-V\right)$, because driving force was linear over the range of voltages examined. The voltage dependencies of activation and steady-state inactivation were described with a single Boltzmann distribution, as follows: $G(V)=G_{\max } /\left(1-\exp \left[\left(V_{1 / 2}-V_{t}\right) / k\right]\right)$, where $G_{\max }$ is the maximal conductance, $V_{1 / 2}$ is the half-maximal voltage, and $k$ is the voltage dependence (slope) of the distribution. The current density of $\mathrm{I}_{\mathrm{T}}$ at each tested membrane potential was determined by dividing the peak current by membrane capacitance.

To quantify the current density of $I_{\mathrm{NaP}}$, five sweeps of the current induced by the ramp protocol were averaged and smoothed with a 10 point boxcar filter. A linear fit from -78 to $-70 \mathrm{mV}$ was made to correct the leak current for each trace. TTX-sensitive sodium current was obtained by subtracting the averaged trace recorded under TTX from that under control conditions (Khaliq and Bean, 2010). The magnitude of $I_{\mathrm{NaP}}$ was measured at membrane potentials ranging from -70 to $-40 \mathrm{mV}$ at $2.5 \mathrm{mV}$ intervals. Current density as a function of membrane potential was calculated by dividing the $I_{\mathrm{NaP}}$ determined at these intervals by membrane capacitance.

\section{Statistics}

Data were analyzed using Prism 6 (GraphPad) and RStudio (RStudio, Inc.), and are reported as the mean \pm SEM. The number of cells per group is indicated by $n$. Normality tests were performed using the test of D'Agostino and Pearson; all data were normally distributed except those in Figure $1 D$ (two-way design) and Figure $7 C$ (one-way design). All data requiring two-way analyses were compared using two-way ANOVA with Bonferroni post hoc analysis; this test is considered sufficiently robust for non-normally distributed data (Fig. $1 D$ only; Underwood, 1997). Data requiring one-way analyses were compared using one-way ANOVA with Bonferroni post hoc analysis or Kruskal-Wallis (KW) test with Dunn's post hoc analysis as dictated by data distribution (in only Fig. 7C, KW). For repeated measurements, two-way 
A

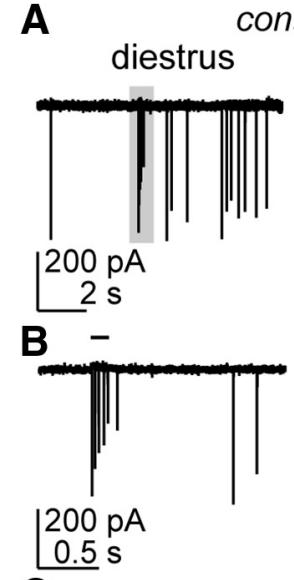

ontrol

proestrus

receptor antagonists

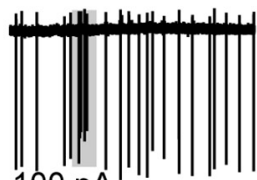

$100 \mathrm{pA}$

$2 \mathrm{~s}$

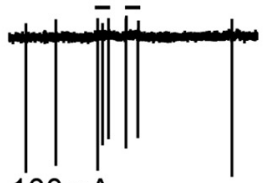

$100 \mathrm{pA}$

C

$0.5 \mathrm{~s}$

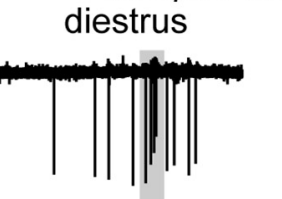

proestrus

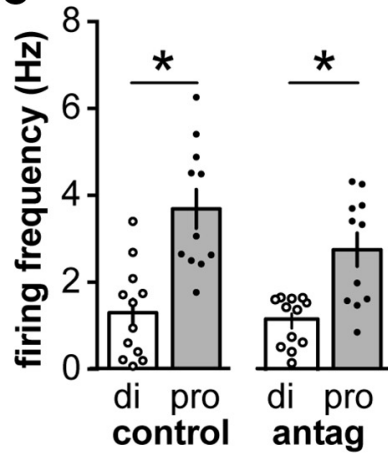

D
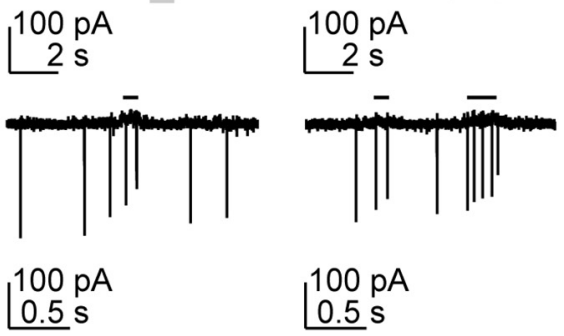

$100 \mathrm{pA}$

$0.5 \mathrm{~s}$

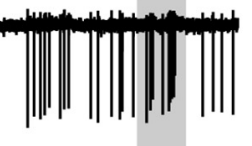

$100 \mathrm{pA}$

E
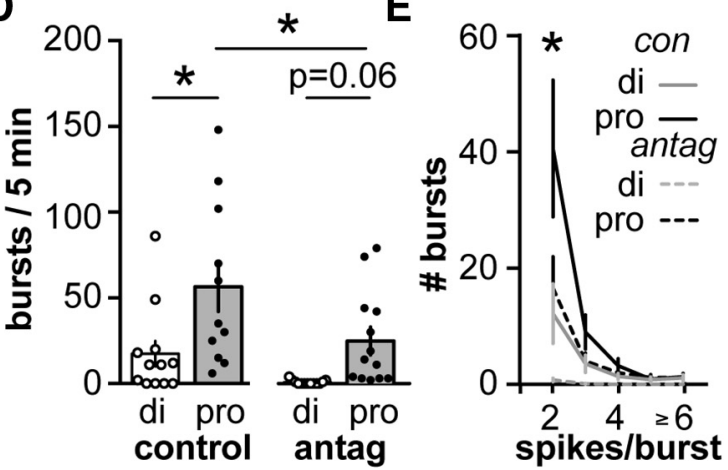

Figure 1. Firing frequency and burst firing in AVPV kisspeptin neurons are regulated by estrous cycle stage. $\boldsymbol{A}$, Representative extracellular recordings of AVPV kisspeptin neurons on di and pro under control conditions (left) and with AMPA, NMDA, and GABA $A$ receptors antagonized (right). $\boldsymbol{B}$, Areas in gray boxes expanded from $\boldsymbol{A}$. Black lines over traces in $\boldsymbol{B}$ indicate identified bursts. $\boldsymbol{C}, \boldsymbol{D}$, Mean \pm SEM firing frequency $(\boldsymbol{C})$ and number of burst events $(\boldsymbol{D})$. $\boldsymbol{E}$, The number of burst events plotted as a function of number of spike per burst on diestrus (gray) and proestrus (black) under control conditions (solid line) and with receptor antagonists (dashed line). Antag, antagonists of ionotropic GABA and glutamate receptors. $* p<0.05$ calculated by two-way ANOVA/Bonferroni or two-way RM ANOVA/Holm-Sidak test.

repeated-measures (RM) ANOVA with Holm-Sidak post hoc analysis was used. For paired data, a two-tailed paired Student's $t$ test was used. For categorical data analysis, a $\chi^{2}$ test of independence or Fisher's exact test of independence was used to test the null hypothesis that categorical variables have no correlation with each other. An $F$ test was used to test the null hypothesis that the SD for groups is equal. Linear regression was used to test the null hypothesis that slope is zero, and to measure the strength of the association [coefficient of determination $\left(r^{2}\right)$ ] between two variables. The null hypothesis was rejected if $p<0.05$. $F_{\mathrm{DFn}, \mathrm{DFd}}$ values from one-way ANOVA, two-way ANOVA, or two-way RM ANOVA are reported in Tables 1-3.

\section{Results}

AVPV kisspeptin neurons exhibit higher spontaneous firing rates and more burst firing on proestrus than diestrus

The firing activity of GFP-identified kisspeptin neurons within the AVPV was monitored using targeted extracellular recordings in acutely prepared brain slices. All cells studied were spontaneously active during the $5 \mathrm{~min}$ ob- servation period under both control conditions and after blocking ionotropic $\mathrm{GABA}_{A}$ and glutamate receptors. Figure $1, A$ and $B$, shows representative firing patterns from each group. Figure $1 C$ shows the average firing frequency of AVPV kisspeptin neurons on diestrus (representing negative feedback) and proestrus (representing positive feedback) under control conditions (di, $n=12$; pro, $n=$ 11 ) or during antagonism of ionotropic receptors conveying GABAergic and glutamatergic fast synaptic transmission (di, $n=12$; pro, $n=11$ ). Consistent with a potential role in relaying estradiol-positive feedback, the spontaneous firing rate of AVPV kisspeptin neurons was greater on the afternoon of proestrus than that of diestrus (Fig. 1C; two-way ANOVA with Bonferroni correction, $p<0.0001$ ). Antagonism of fast synaptic transmission via NMDA, AMPA, and $\mathrm{GABA}_{\mathrm{A}}$ receptors did not alter the firing rate during either cycle stage $(p>0.9)$. The cycle-dependent difference in firing frequency was maintained after blocking ionotropic receptors $(p=0.0019)$.

Extracellular recordings were also used to evaluate burst versus single-spike firing. Bursts were defined as action potentials occurring within $105 \mathrm{~ms}$ of each other with progressively decreased amplitude and an upshift of 
Table 1: Two-way ANOVA parameters for comparison among groups: cells from diestrus vs proestrus mice

\begin{tabular}{llll}
\hline Parameter (figure) & Estrous cycle stage & Antagonists & Interaction \\
Extracellular recordings & & & \\
Firing frequency (Fig. 1C) & $F_{(1,42)}=37.3 * * *$ & $F_{(1,42)}=3.0$ & $F_{(1,42)}=1.2$ \\
Bursts/5min (Fig. 1D) & $F_{(1,46)}=14.8 * * *$ & $F_{(1,46)}=8.4 * *$ & \\
Whole-cell recordings & & $F_{(1,46)}=0.8$ \\
Input resistance (Fig. 2D) & $F_{(1,47)}=2.3$ & $F_{(1,47)}=7.5 * * a$ & $F_{(1,47)}=4.2 *$ \\
Input resistance (Fig. 2C) & $F_{(1,37)}=1.7$ & $F_{(1,30)}=7.0 * \mathrm{~b}$ & $F_{(1,37)}=1.2$ \\
Rebound: initial IF (Fig.2F) & $F_{(1,30)}=69.3 * * *$ & $F_{(1,34)}=7.3 * \mathrm{~b}$ & $F_{(1,34)}=32.0 * * *$ \\
Rebound: overall frequency (Fig. 2G) & $F_{(1,34)}=34.8 * * *$ & $F_{(1,37)}=0.4 \mathrm{~b}$ & $F_{(1,37)}=0.3$ \\
First spike latency (Fig. 3B) & $F_{(1,37)}=0.8$ & $F_{(1,37)}=0.7 \mathrm{~b}$ & 0.01 \\
Rate of rise (Fig. 3C) & $F_{(1,37)}=0.6$ & $F_{(1,37)}=22.6 * * * \mathrm{~b}$ & $F_{(1,37)}=3.8$ \\
Threshold (Fig. 3D) & $F_{(1,37)}=0.1$ & $F_{(1,37)}=2.8 \mathrm{~b}$ & $F_{(1,37)}=0.2$ \\
FWHM (Fig. 3E) & $F_{(1,37)}=2.1$ & $F_{(1,37)}=35.3 * * * \mathrm{~b}$ & $F_{(1,37)}=0.1$ \\
AHP amplitude (Fig. 3F) & $F_{(1,37)}=0.7$ & $F_{(1,37)}=26.2 * * * \mathrm{~b}$ & $F_{(1,37)}=0.1$ \\
AHP time (Fig. 3G) & $F_{(1,37)}=1.6$ & & \\
\hline
\end{tabular}

${ }^{a}$ Cesium antagonist.

${ }^{b}$ Tonic vs DIB.

$* p<0.05 ; * * p<0.01 ; * * * p<0.001$.

baseline (Fig. 1B, black lines above traces). AVPV kisspeptin neurons exhibit spontaneous burst firing during both diestrus $(n=12)$ and proestrus $(n=11)$, but the number of the burst events per 5 min was higher on proestrus (Fig. 1D, two-way ANOVA with Bonferroni correction, $p=0.005$ ). The number of the burst events per 5 min was decreased on proestrus in the presence of ionotropic glutamate and $\mathrm{GABA}_{\mathrm{A}}$ receptor antagonists (di, $n=$ 14; pro, $n=13 ; p=0.02$ ) but was not changed on diestrus $(p=0.14)$. Although it appears that the increase in the number of bursts in 5 min on proestrus compared with diestrus was maintained when ionotropic receptors were blocked, the $p$ value was just short of that accepted for significance (Fig. 1D, $p=0.06$ ).

We next analyzed the numbers of spikes per burst as a function of cycle stage (Fig. 1E, two-way RM ANOVA with Holm-Sidak control: di, $n=12$; pro, $n=11$; receptor antagonist: di, $n=14$; pro, $n=13$ ). Under control conditions, there were more bursts consisting of two spikes on proestrus than diestrus $(p<0.0001)$. After the blocking of ionotropic glutamate and $\mathrm{GABA}_{A}$ receptors, the number of two-spike bursts was decreased during both cycle stages (di, $p=0.01$; pro, $p<0.0001$ ), but was still higher on proestrus than diestrus ( $p=0.005)$. No difference in the number of bursts with three or more spikes was detected between cycle stages either with or without ionotropic receptor antagonists. Following addition of the receptor antagonists, however, no cell studied during diestrus $(n=13)$ fired bursts with more than two spikes. This is in contrast to control conditions, under which 7 of 12 cells studied on diestrus fired bursts of three or more spikes. Cells studied on proestrus, in contrast, fired bursts with three or more spikes under control conditions as well as when ionotropic receptors were blocked. These observations suggest that both intrinsic properties and fast synaptic transmission likely contribute to burst firing in AVPV kisspeptin neurons, and that the relative contributions may change with cycle stage. We thus focused our remaining studies on the intrinsic properties of these neurons.

\section{Depolarization induces two firing patterns: tonic firing and depolarization-induced bursts}

To begin to understand the contributions of the intrinsic properties of AVPV kisspeptin neurons to burst firing, we performed whole-cell current-clamp recordings on brain

Table 2: Two-way repeated-measures ANOVA for whole-cell comparison among groups: cells from diestrus vs proestrus mice

\begin{tabular}{llll}
\hline Parameter (figure) & Estrous cycle stage & Interaction & Matching \\
Control: spike/burst (Fig.1E) & $F_{(1,21)}=5.6 *$ & $F_{(4,84)}=6.7 * * *$ & $F_{(21,84)}=2.3 * *$ \\
Antagonists: spike/burst (Fig.1E) & $F_{(1,25)}=11.6 * *$ & $F_{(4,100)}=11.4 * * *$ & $F_{(25,100)}=2.8 * * *$ \\
I $_{\text {Tensity (Fig. 4I) }}$ dent & $F_{(1,20)}=4.4 *$ & $F_{(8,160)}=4.3 * * *$ & $F_{(20,160)}=4.7 * * *$ \\
$I_{\text {NaP }}$ density (Fig. 5D) & $F_{(1,22)}=5.4 *$ & $F_{(22,264)}=3.6 * * *$ & $F_{(12,264)}=15.7 * * *$ \\
Diestrus: tonic vs DIB (Fig. 2B) & $F_{(1,16)}=84.5 * * * a$ & $F_{(6,96)}=82.6 * * *$ & $F_{(16,96)}=2 * *$ \\
Proestrus: tonic vs DIB (Fig. 2B) & $F_{(1,17)}=42.2 * * * a$ & $F_{(5,85)}=88.1 *$ & $F_{(17,85)}=5.1 * * *$ \\
Depolarize: IF (Fig. 4D) & $F_{(1,9)}=46.1 * * * a$ & $F_{(2,18)}=52.2 * * *$ & $F_{(9,18)}=11.2 * * *$ \\
$I_{\text {NaP }}$ density (Fig. 5E) & $F_{(1,16)}=7.3 * \mathrm{~b}$ & $F_{(12,192)}=5.7 * * *$ & $F_{(16,192)}=12.7 * * *$ \\
$I_{\text {NaP }}$ density (Fig. 5E) & $F_{(1,18)}=0.8 \mathrm{c}$ & $F_{(12,216)}=1.2$ & $F_{(18,216)}=17.8 * * *$ \\
$I_{\text {NaP }}$ density (Fig. 6D) & $F_{(1,10)}=3.5 \mathrm{~d}$ & $F_{(12,120)}=2.3 * *$ & $F_{(10,120)}=10.2 * * *$
\end{tabular}

aTonic vs DIB.

${ }^{b}$ Diestrus: rebound vs no rebound.

${ }^{c}$ Rebound: diestrus vs proestrus.

${ }^{d} 4$-AP sensitive vs insensitive.

$* p<0.05 ; * * p<0.01 ; * * * p<0.001$. 
Table 3: One-way ANOVA parameters for comparison among groups: OVX, OVX $+E$, and OVX $+E+P$

\begin{tabular}{ll}
\hline Parameter (figure) & Mice \\
Extracellular recording & OVX, OVX+E and OVX+E+P \\
Firing frequency (Fig. 7B) & $F_{(2,45)}=12.7 * * *$ \\
Whole-cell Recordings & OVX, OVX+E and OVX+E+P \\
& $F_{(2,27)}=3.9 *$ \\
First spike latency (Fig. 7F) & $F_{(2,27)}=6.3 * *$ \\
FWHM (Fig. 7G) & $F_{(2,27)}=7.6 * *$ \\
AHP amplitude (Fig. 7H) & $F_{(2,27)}=35.9 * * *$ \\
Sag potential (Fig. 8F) &
\end{tabular}

Two-way repeated-measures ANOVA for comparison among groups: OVX and OVX $+\mathrm{E}$

$\mathrm{I}_{\mathrm{T}}$ (Fig. 8C)

$\mathrm{I}_{\mathrm{NaP}}$ (Fig. 8E)

One-way ANOVA nonparameters KW test for

comparison among groups: OVX, OVX $+E, O V X+E+P$

Extracellular recording

Bursts/5 min (Fig. 7C)

$$
\begin{aligned}
& \text { OVX vs OVX }+E \\
& F_{(1,18)}=8.0 * \\
& F_{(1,19)}=5.8 *
\end{aligned}
$$

OVX, OVX $+\mathrm{E}$ and $\mathrm{OVX}+\mathrm{E}+\mathrm{P}$

KW statistic 6.8

$* p<0.05 ; * * p<0.01 ; * * * p<0.001$.

slices in the presence of APV, CNQX, and picrotoxin to antagonize effects attributable to the activation of ionotropic glutamate and $\mathrm{GABA}_{\mathrm{A}}$ receptors. AVPV kisspeptin neurons exhibited two distinct firing patterns in response to depolarizing steady-state current injections of similar magnitude $(25 \pm 5 \mathrm{pA}, 0.5 \mathrm{~s})$ initiated from $-70 \pm 2 \mathrm{mV}$. Representative examples under control conditions are shown in Figure $2 A$. Tonic firing was defined as a steady firing rate with a consistent instantaneous frequency (IF; overall IF, $22 \pm 1 \mathrm{~Hz}$; initial IF, $29 \pm 2 \mathrm{~Hz}$ vs final IF, $18 \pm$ $1 \mathrm{~Hz}$; paired $t$ test, $p<0.0001$; SD of IF, $4 \pm 1 \mathrm{~Hz} ; n=25$ ). Depolarization-induced bursting (DIB) cells exhibited an initial burst containing three to four spikes followed by mild frequency accommodation (overall IF, $73 \pm 3 \mathrm{~Hz}$; initial IF, $113 \pm 4 \mathrm{~Hz}$ vs final IF, $13 \pm 1 \mathrm{~Hz}$; paired $t$ test, initial IF vs final IF, $p<0.0001$; SD of IF, $36 \pm 2 \mathrm{~Hz} ; n=$ 16; $F$ test, tonic vs DIB SD, $p<0.0001)$. Tonic and DIB firing patterns were observed to a similar extent on both cycle stages studied (tonic vs DIB: di, $64 \%$ vs $36 \%, n=$ 19 ; pro, $59 \%$ vs $41 \%, n=22$; Fisher's exact test, $p>0.9$ ). We averaged the instantaneous firing frequency of each cell type on each cycle stage and plotted this as a function of spike interval number (Fig. $2 B$; tonic: di, $n=12$; pro, $n=13$; DIB: di, $n=7$; pro, $n=9$ ). The initial IF of DIB cells was fourfold larger than that in tonic cells on both cycle stages (Fig. 2B, two-way RM ANOVA with HolmSidak test, di, $p<0.0001$; pro, $p<0.0001$ ). The frequency plots did not show any difference between cycle stages in tonic or DIB cells $(p>0.1)$.

We next examined the action potential properties of tonic and DIB cells. In Figure $3 A$, the first action potential evoked by the minimum necessary depolarizing current injection is shown in tonic and DIB cells on diestrus (left) and proestrus (right). We measured and compared several action potential parameters between cycle stages and cell types (tonic: di, $n=12$; pro, $n=13$; DIB: di, $n=7$; pro, $n=9$ ). As summarized in Figure $3 B-G$, the action potential threshold, amplitude, and timing of the AHP potential showed a cell firing type-dependent but not cycledependent change (two-way ANOVA with Bonferroni correction, all post hoc, $p<0.001$ ). The first spike latency, rate of rise, and FWHM of the action potential did not change among groups ( $p>0.1$ for all post hoc tests). The minimal necessary current injection (rheobase) itself was not different between cycle stages or cell types (di: tonic, $9.6 \pm 1.0 \mathrm{pA}$; DIB, $13.3 \pm 2.2 \mathrm{pA}$; pro: tonic, $10.8 \pm 0.8$ $\mathrm{pA}$; DIB, $10.1 \pm 1.1 \mathrm{pA}$; two-way ANOVA with Bonferroni correction, $p>0.1$ for all comparisons).

There was no difference in the $R_{\text {in }}$ of tonic firing cells on diestrus versus proestrus (Fig. 2C; two-way ANOVA with Bonferroni correction, $p=0.47$; di, $n=12$; pro, $n=13$ ), but the $R_{\text {in }}$ of DIB cells was greater on proestrus than diestrus (di, $n=7$; pro, $n=9 ; p=0.04$ ). Within a cycle stage, there was no firing pattern-dependent (tonic vs DIB) difference in $\mathrm{R}_{\text {in }}$ (di, $p=0.91$; pro, $p=0.22$ ). The membrane capacitance was not different among groups (data not shown; $p>0.9$ ). When grouped by cycle stage, cells recorded on proestrus had a greater $R_{\text {in }}$ compared with those recorded on diestrus (di, $n=15$; pro, $n=15$; $p=0.01$ ). This cycle-dependent difference in $R_{\text {in }}$ was eliminated in recordings using a cesium-based pipette solution (Fig. $2 D ; n=11$ each; $p=0.88$ ). Because $\mathrm{R}_{\text {in }}$ exhibited a cycle-dependent difference between diestrus and proestrus, and only DIB cells showed a cycledependent difference, it is likely DIB cells contribute the difference in $R_{\text {in }}$ under control conditions. The elimination of a difference in $\mathrm{R}_{\text {in }}$ with $\mathrm{Cs}^{+}$internal suggests a $\mathrm{Cs}^{+}-$ sensitive potassium conductance under estrous cycle regulation may contribute to the difference in $R_{\text {in }}$ values.

\section{Termination of hyperpolarization: rebound bursts and their relationship to the firing pattern during depolarization}

In addition to depolarization-induced firing, many neurons exhibit firing upon termination of a hyperpolarizing stimulus (Perez-Reyes, 2003; Tadayonnejad et al., 2010). We 

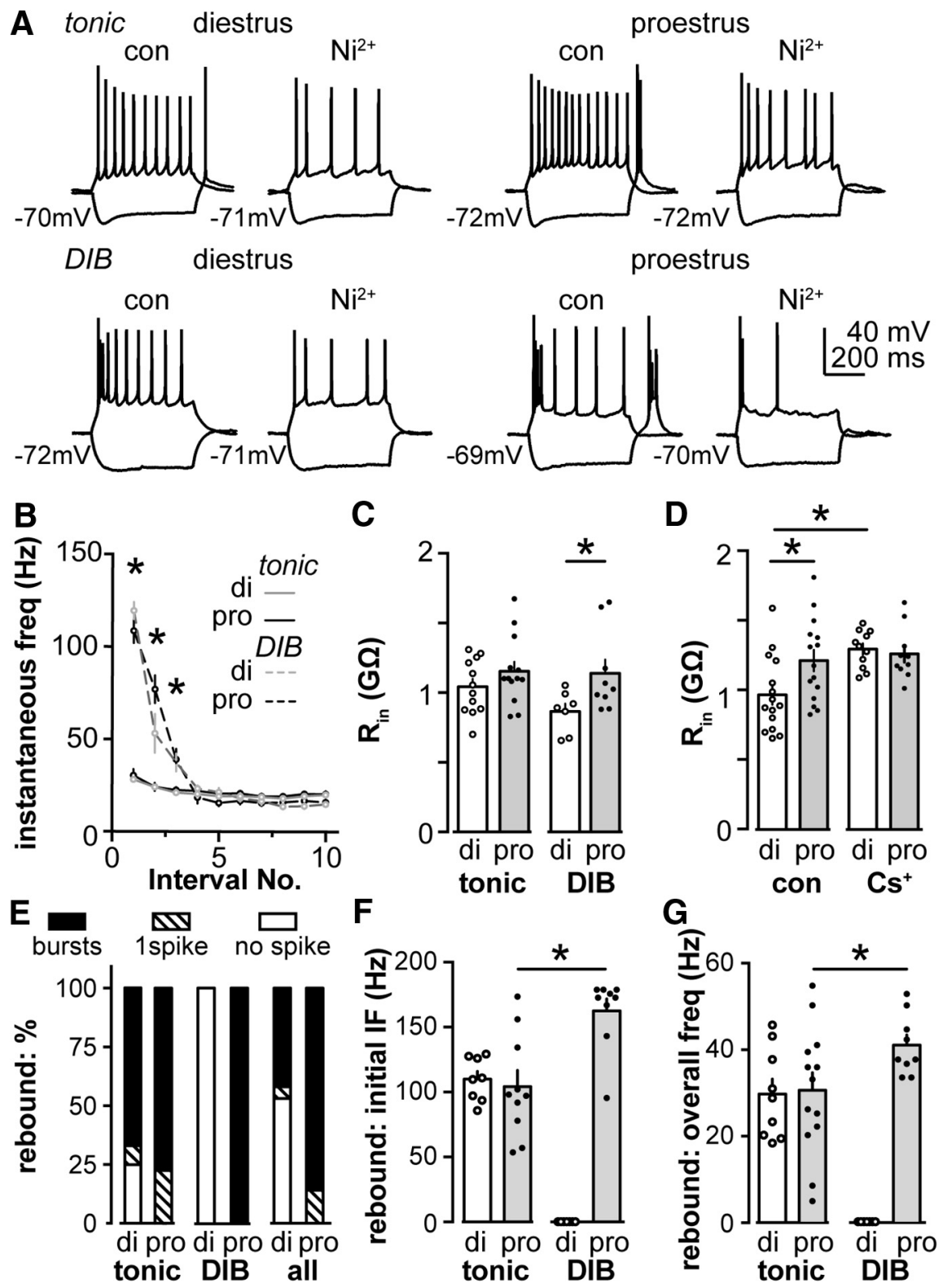

Figure 2. Depolarization and removal of hyperpolarization both induce distinct firing properties. $\boldsymbol{A}$, Representative firing properties of tonic and DIB cells on diestrus and proestrus under control conditions and during treatment with $\mathrm{Ni}^{2+}(100 \mu \mathrm{M})$. B, Mean $\pm \mathrm{SEM} I \mathrm{~F}$ of tonic (solid line) and DIB (dash line) cells on di (gray) and pro (black) plotted as a function of spike interval number. $\boldsymbol{C}, \mathrm{R}_{\text {in }}$ for tonic and DIB cells on diestrus and proestrus. $\boldsymbol{D}, \mathrm{R}_{\mathrm{in}}$ for cells on diestrus and proestrus assessed using physiological (con) and Cs ${ }^{+}$-based pipette solution. $\boldsymbol{E}$, Distribution of cells that generated rebound bursts (black bar), one rebound spike (hatched bar), or no rebound spikes (white bar) on diestrus and proestrus for tonic, DIB, and all cells combined. $\boldsymbol{F}$, $\boldsymbol{G}$, Initial IF (F) and overall frequency (G) of rebound bursts in tonic and DIB cells on diestrus and proestrus. $* p<0.05$ calculated by two-way ANOVA with Bonferroni correction or two-way RM ANOVA and Holm-Sidak test.

tested whether AVPV kisspeptin neurons exhibit so-called rebound bursts. Cells were injected with hyperpolarizing current to achieve a membrane potential of $-105 \pm 3 \mathrm{mV}$. After the termination of hyperpolarization, most AVPV kisspeptin neurons exhibited rebound bursts (two or more spikes), whereas, the rest showed either single-rebound spikes or no rebound, as indicated in the representative examples in Figure $2 A$ (control). The type of rebound events (bursts, single spike, or no spike) differed with cycle stage (Fig. $2 E$, right; di, $n=19$; pro, $n=22 ; \chi^{2}$ test, $p<0.001$ ).

We next examined whether there was a relationship between the observed firing patterns during depolarization and the rebound patterns following the termination of hyperpolarization. Most cells (di, 8 of 12; pro, 10 of 13) that fired tonically upon depolarization had rebound bursts. The remaining cells studied on proestrus (3 of 13 cells) fired a single spike rebound, whereas most other 

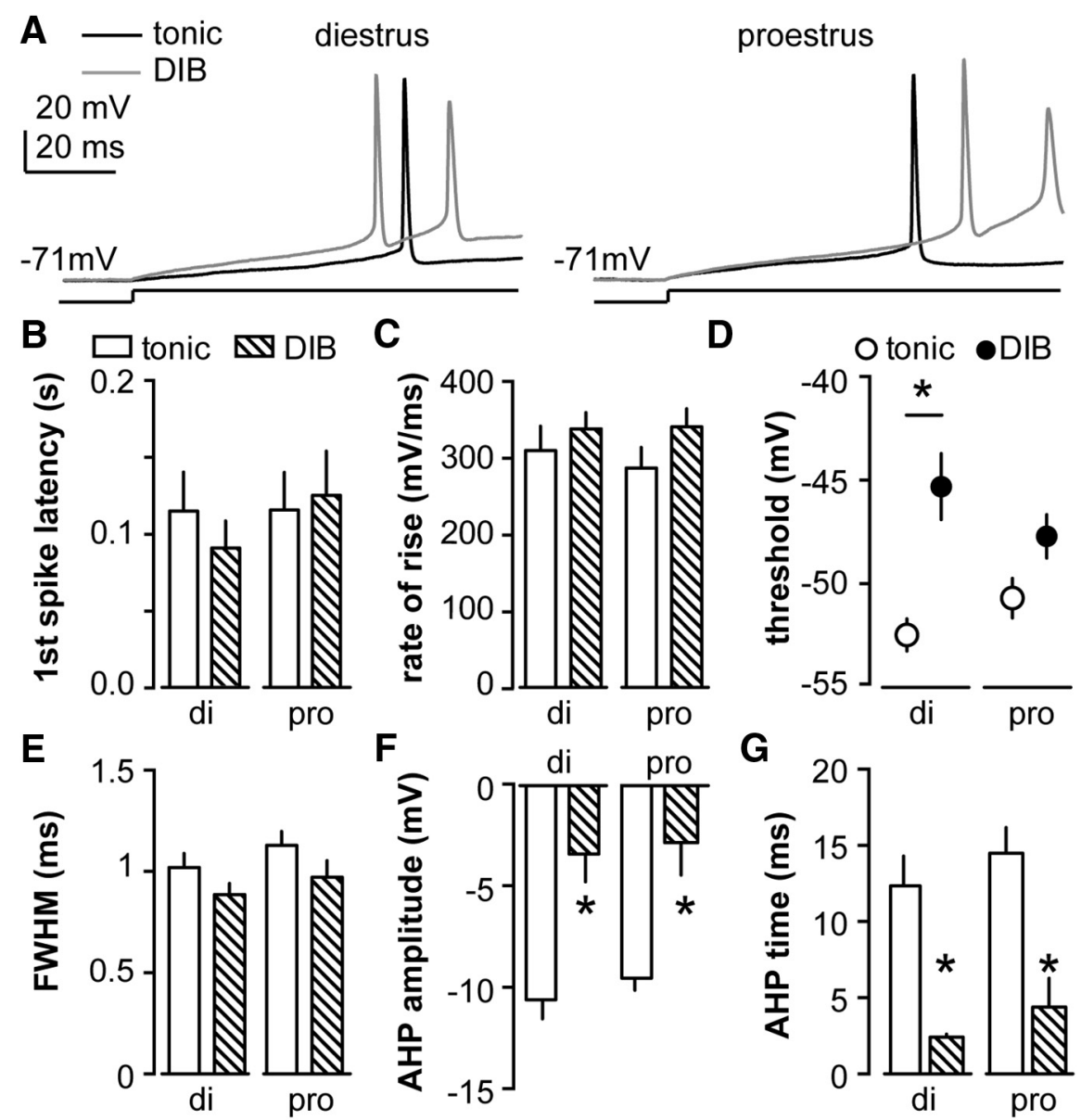

Figure 3. Action potential properties of AVPV kisspeptin neurons depend on firing pattern during depolarization but not cycle stage. $\boldsymbol{A}$, Representative first action potential evoked via minimal necessary depolarizing current in tonic (black) and DIB (gray) cells on diestrus (left) and proestrus (right). The line under the action potentials indicate timing of current injection (10 pA for examples shown except $15 \mathrm{pA}$ for the DIB cell on proestrus). $\boldsymbol{B}-\boldsymbol{F}$, Mean \pm SEM action potential parameters in tonic cells (open bar for $\boldsymbol{B}, \boldsymbol{C}$, and $\boldsymbol{E}-\boldsymbol{G}$; open circle for $\boldsymbol{D}$ ) and DIB cells (hatched bar for $\boldsymbol{B}, \boldsymbol{C}$, and $\boldsymbol{E}-\boldsymbol{G}$; black circle for $\boldsymbol{D}$ ) on di and pro, including first spike latency $(\boldsymbol{B})$, action potential rate of rise $(\boldsymbol{C})$, threshold $(\boldsymbol{D})$, FWHM $(\boldsymbol{E})$, AHP potential amplitude $(\boldsymbol{F})$, and AHP time on diestrus and proestrus $(\boldsymbol{G})$. $* p<0.05$ calculated by two-way ANOVA/Bonferroni test tonic vs DIB.

cells studied on diestrus showed no rebound ( 3 of 12 cells), and one cell showed a single spike rebound. This distribution did not differ with cycle stage (Fig. 2E, left; $\chi^{2}$ test, $p=0.1$ ). Strikingly, cells that fired DIB patterns had rebound bursts only on proestrus (Fig. 2E, middle; di, $n=$ 7 ; pro, $n=10$ ).

We focused on rebound bursts (two or more spikes) because they are more likely than single rebound spikes to achieve a sufficient change in intracellular $\mathrm{Ca}^{2+}$ to influence neurosecretion and thus postsynaptic events (Jacobs and Meyer, 1997). We characterized rebound bursts by measuring the initial IF (between spikes 1 and 2) and the overall frequency of rebound bursts (the number of spikes divided by the duration from the termination of hyperpolarization to the peak of the last rebound spike in the bursts). The initial IF and the overall frequency of bursts in tonic and DIB cells showed a firing patterndependent difference (Fig. $2 F$, initial IF; tonic: di, $n=8$; pro, $n=10$; DIB: di, $n=7$; pro, $n=9$; Fig. $2 G$, overall frequency; tonic: di, $n=9$; pro, $n=13$; DIB: di, $n=7$; pro, $n=9$; two-way ANOVA and Bonferroni correction). On proestrus, the initial IF and overall frequency was higher in DIB cells than tonic cells (IF, $p<0.0001$; overall frequency, $p=0.03$ ). There was no cycle-dependent change of rebound burst frequency in tonic cells (both initial and overall, $p>0.9$ ), markedly different from DIB cells, which did not exhibit rebound bursts on diestrus. Our observations thus indicate that DIB and tonic cells show different responses to the termination of hyperpolarization. The different firing signatures may be linked to differences in specific ionic currents.

\section{Estrous cycle regulation of T-type calcium current properties and its role in depolarization and rebound firing patterns}

The observation that cells with different depolarizationinduced firing patterns could exhibit different rebound patterns based on cycle stage led us to examine potential underlying mechanisms in greater detail. We first tested the membrane response to the termination of hyperpolar- 
ization in the absence (to assess initial IF) and the presence of TTX to assess the depolarizing membrane response (Fig. 4A). After TTX application, marked membrane depolarization, often attributable to the activation of T-type calcium channels (Suzuki and Rogawski, 1989; Molineux et al., 2006), was observed following the termination of hyperpolarization in cells that fired rebound bursts but not in cells firing either single or no rebound spikes. This was not dependent on cycle stage but rather on the pre-TTX rebound profile. Figure $4 B$ shows the correlation between the rebound IF and the amplitude of the depolarization. Rebound IF was positively correlated with rebound depolarization amplitude for tonic cells on both diestrus and proestrus (Fig. 4B; di: $r^{2}=0.47 ; p=$ $0.045 ; n=9$; pro: $\left.r^{2}=0.84 ; p=0.004 ; n=9\right)$. In contrast, there was no correlation between these properties for DIB cells on proestrus ( $\left.n=7 ; r^{2}<0.001 ; p=0.98\right)$.

The above observations suggest that, in addition to possible differences in currents driving action potential properties (Fig. 3D,F,G), other ionic currents might contribute to the difference between tonic firing and DIB cells. In other neuron types, the amplitude of rebound depolarization directly correlates with the size of transient $\mathrm{Ca}^{2+}$ currents (Suzuki and Rogawski, 1989; Molineux et al., 2006). We tested the effect of $\mathrm{Ni}^{2+}(100 \mu \mathrm{M}$, a dose that is fairly specific for T-type channels; Lee et al., 1999) on depolarization-induced firing patterns and hyperpolarization-induced rebound bursts. $\mathrm{Ni}^{2+}$ decreased the IF of the depolarization-induced bursts to approximately half (Fig. $2 A$, summary data; Fig. $4 G, n=8$; paired $t$ test, $p=0.0002$ ). The initial IF after $\mathrm{Ni}^{2+}$ application was still higher in DIB cells than that in tonic cells under control $\left(\mathrm{no} \mathrm{Ni}{ }^{2+}\right)$ conditions $(p=0.006)$. The initial IF of tonic cells also decreased after $\mathrm{Ni}^{2+}$ application (Fig. 4G; $n=11$; paired $t$ test, $p=0.049$ ), but to a lesser extent (decreased 19 $\pm 7 \%$ in tonic vs $54 \pm 6 \%$ in DIB cells; Student's $t$ test, $p=$ 0.001). Since T-type channels are voltage dependent, we altered the initial membrane potential to $-65,-70$, or -75 $\mathrm{mV}$, and then applied a current injection of $25 \pm 5 \mathrm{pA}$ to depolarize the membrane to generate $n \pm 2$ action potential spikes ( $n$, action potential numbers generated at $-70 \mathrm{mV}$, with $25 \pm 5$ pA current injection; Fig. $4 C$ ). The IF of DIB cells was decreased because the initial membrane potential was depolarized from -75 to -70 to $-65 \mathrm{mV}$ (Fig. 4D; tonic, $n=$ 5; DIB, $n=6$; two-way RM ANOVA and Holm-Sidak test, all post hoc in DIB, $p<0.0001)$. No change in the IF of tonic cells was observed $(p>0.1)$. Rebound bursts were eliminated after $\mathrm{Ni}^{2+}$ application in the majority of cells recorded on both cycle stages (di, 7 of 8 ; pro, 6 of 7). The rebound bursts that $\mathrm{Ni}^{2+}$ did not block were reduced from three to four spikes per bursts to a single spike. Together, these observations suggest a substantial role for $\mathrm{Ni}^{2+}$-sensitive currents, perhaps $I_{\mathrm{T}}$, in both depolarization-induced and rebound firing patterns.

Persistence of single rebound spikes could be attributable to $100 \mu \mathrm{M} \mathrm{Ni}{ }^{2+}$ not being sufficient to block all channels carrying $I_{\mathrm{T}}$. Alternatively, but not exclusively, other channels might affect the occurrence of the rebound bursts. We first measured T-type current properties in AVPV kisspeptin neurons. To facilitate the isolation of $I_{\mathrm{T}}$, a $\mathrm{Cs}^{+}$-based pipette solution was used to reduce potas- sium conductances, and TTX was bath applied to block fast voltage-dependent sodium channels. All cells recorded on diestrus and proestrus exhibited $I_{\mathrm{T}}$ based on the voltage dependence of the observed current. Figure $4 E$ shows the representative whole-cell voltage-clamp traces of $I_{\mathrm{T}}$ triggered by the voltage protocol described in Materials and Methods. The application of $100 \mu \mathrm{M} \mathrm{Ni}{ }^{2+}$ blocked a majority of the current $(73.1 \pm 0.4 \% ; n=4)$ evoked at a test pulse of -40 from $-110 \mathrm{mV}$ (Fig. $4 F$ ). This suggests that the currents observed are $I_{\mathrm{T}}$ and that most, but not all, of the current is sensitive to $100 \mu \mathrm{M} \mathrm{Ni}^{2+}$.

The conductance-voltage relationship was fit with a Boltzmann function. Neither the slope factor $k$ nor the voltage dependence of activation or inactivation were different between cycle stages (Fig. $4 H ; n=11$ each; $V_{1 / 2}$ activation: di, $-54.5 \pm 1.3 \mathrm{mV}$; pro, $-53.5 \pm 1.3 \mathrm{mV} ; p=$ 0.59; slope factor $\mathrm{k}$ : di, $5.1 \pm 0.4$; pro, $5.5 \pm 0.4 ; p=0.59$; $\mathrm{V}_{1 / 2}$ inactivation: $n=12$ each; di, $-66.4 \pm 1.6 \mathrm{mV}$; pro, $-67.6 \pm 1.5 \mathrm{mV} ; p=0.56$; slope factor $\mathrm{k}$ : di, $-3.2 \pm 0.1$; pro, $-3.0 \pm 0.1 ; p=0.11$, Student's $t$ test). The current density, however, was greater on proestrus than diestrus at membrane potentials between -50 and $-30 \mathrm{mV}$ (Fig. $4 I ; n=11$; two-way RM ANOVA and Holm-Sidak test, $p$ $<0.01)$. The change in current density was not attributable to a difference in either membrane capacitance or series resistance between groups.

\section{Other voltage-dependent currents modifying rebound bursts: persistent sodium current and A- type potassium current}

The generation of rebound bursts can be a complex interplay of multiple channel types that pass currents in inward and outward directions. Since rebound firing is $\mathrm{Ni}^{2+}$ sensitive, $\mathrm{I}_{\mathrm{T}}$ likely plays a dominant role in generating rebound bursts. The lower likelihood of firing rebound bursts on diestrus versus proestrus may be attributable to estrous cycle regulation of other currents that either facilitates or inhibits rebound burst generation. One candidate for a facilitating current is the $\mathrm{I}_{\mathrm{NaP}}$, as it activates at membrane potentials in the subthreshold range.

We characterized $\mathrm{I}_{\mathrm{NaP}}$ in AVPV kisspeptin neurons on diestrus and proestrus using slow (10 mV/s) voltage ramps from -80 to $-20 \mathrm{mV}$ (Fig. $5 A$, top). The rampinduced current was linear from $-80 \mathrm{mV}$ to approximately $-65 \mathrm{mV}$ (Fig. 5A, bottom). At membrane potentials more depolarized than $-65 \mathrm{mV}$, we observed a persistent inward current that peaked near $-40 \mathrm{mV}$. This current was blocked by TTX, suggesting the net current is $\mathrm{I}_{\mathrm{NaP}}$ (Fig. $5 B)$. The current density of $\mathrm{I}_{\mathrm{NaP}}$ was higher on proestrus than diestrus from -55 to $-47.5 \mathrm{mV}$ (Fig. $5 C, D ; n=12$ each; two-way RM ANOVA and Holm-Sidak test: -55 $\mathrm{mV}, p=0.057 ;-52.5 \mathrm{mV}, p=0.002 ;-50 \mathrm{mV}, p=0.01$; and $-47.5 \mathrm{mV}, p=0.045)$.

Because $I_{\mathrm{NaP}}$ appears to be regulated by the estrous cycle, we tested whether it facilitates rebound burst generation. We divided cells on diestrus into those exhibiting rebound bursts (two or more spikes) versus those not exhibiting any rebound spikes, and compared the $\mathrm{I}_{\mathrm{NaP}}$ current density of these two groups with that of cells on proestrus (all of which had rebound bursts with two or 

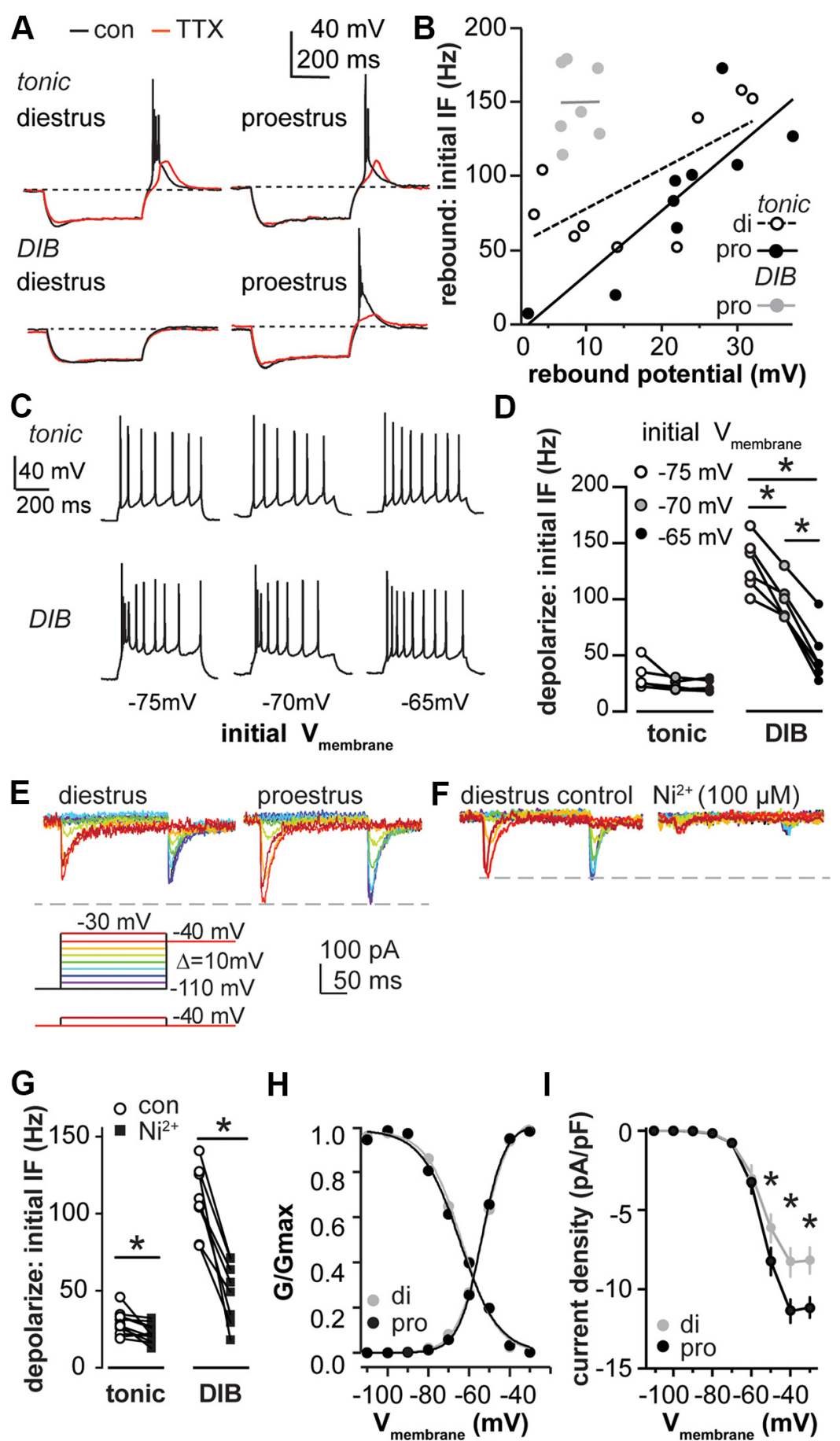

Figure 4. $\mathrm{Ni}^{2+}$-sensitive current is critical for bursting patterns and is under estrous cycle regulation. $\boldsymbol{A}$, Representative examples for rebound potential of tonic and DIB cells on diestrus and proestrus under control conditions (black) and then tested with TTX (1 $\mu \mathrm{M}$ ) application (red). Dashed lines indicate $-70 \mathrm{mV}$. B, Positive correlation between rebound depolarization and initial IF was observed in tonic cells on di (open circle fitted with dashed line) and pro (black circle fitted with solid black line) but not in DIB cells on proestrus (gray circle fitted with gray line). C, Representative examples of the depolarization-induced firing pattern of tonic and DIB cells initiated at $-65,-70$, and $-75 \mathrm{mV}$. $\boldsymbol{D}$, IF was dependent on the preceding membrane potential in tonic and DIB cells, each line connects values from the same cells at different membrane potentials. $\boldsymbol{E}$, Voltage protocols for $\mathrm{I}_{\mathrm{T}}$ isolation; bottom protocol was subtracted from the top to remove HVA contamination from step $-30 \mathrm{mV}$ (bottom, left). Representative isolated $\mathrm{I}_{\mathrm{T}}$ on diestrus (top, left) and proestrus (top,right), each color represents a tested voltage. $\boldsymbol{F}$, Isolated $\mathrm{I}_{\mathrm{T}}$ was blocked by $\mathrm{Ni}^{2+}(100 \mu \mathrm{M})$. $\boldsymbol{G}$, Initial IF of depolarization-induced firing for tonic and DIB cells under control conditions and with $\mathrm{Ni}^{2+}(100 \mu \mathrm{m})$ application, paired. $\boldsymbol{H}$, Activation and inactivation of $\mathrm{I}_{\mathrm{T}}$ conductance was plotted and fit with Boltzmann function to derive $V_{1 / 2}$ and $k$ value on diestrus (gray dots fitted with gray line) and proestrus (black dots fitted with black line). $I$, Mean \pm SEM current density of $\mathrm{I}_{\mathrm{T}}$ on diestrus and proestrus. $* p<0.05$ calculated by two-way RM ANOVA and Holm-Sidak test. 

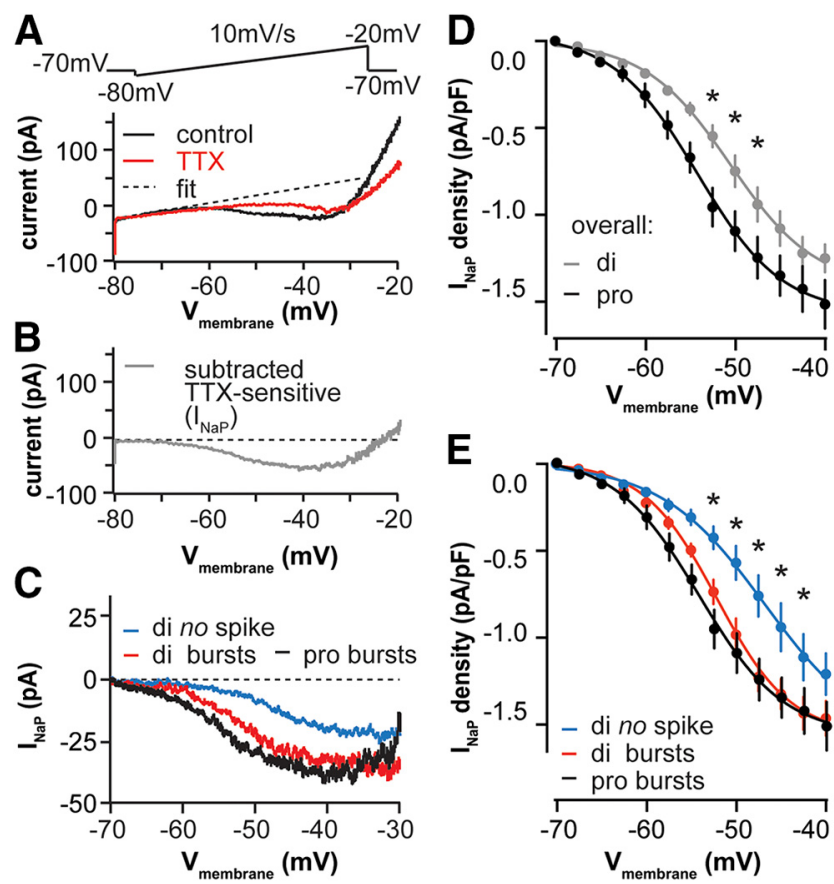

Figure 5. $I_{\mathrm{NaP}}$ facilitates rebound burst generation and is regulated by the estrous cycle. $\boldsymbol{A}$, ramp protocol (top) and representative raw currents (bottom) under control conditions (black) and after application of TTX (red). Dashed line indicates the linear fit to correct for leak current. B, Representative TTX-sensitive $I_{\mathrm{NaP}}$ obtained by subtracting the TTX trace from the control trace in $\boldsymbol{A}$ after linear fit of each. $\boldsymbol{C}$, Representative $\mathrm{I}_{\mathrm{NaP}}$ in cells that exhibit rebound bursts (red) or no rebound spikes (blue) on diestrus and those that exhibited rebound bursts on proestrus (black). $\boldsymbol{D}, \boldsymbol{E}$, Mean $\pm S E M I_{\mathrm{NaP}}$ current density on di vs pro $(\boldsymbol{D})$ and with cells parsed by cycle stage and rebound firing $(\boldsymbol{E}) . * p<0.05$ calculated by two-way RM ANOVA and Holm-Sidak test.

more spikes). Figure $5 \mathrm{C}$ shows a representative $\mathrm{I}_{\mathrm{NaP}}$ for each group, and Figure $5 E$ shows the quantitative current density comparison among groups. $I_{\mathrm{NaP}}$ current density was lower in cells on diestrus that do not fire rebound bursts $(n=11)$ than in those that fire rebound bursts $(n=$ 9) at membrane potentials between -52.5 and $-42.5 \mathrm{mV}$ (two-way RM ANOVA and Holm-Sidak test, $p<0.05$ ). $I_{\mathrm{NaP}}$ current density between cells exhibiting rebound bursts on diestrus $(n=9)$ and proestrus $(n=11)$ was not different $(p>0.6)$. This suggests that cells that do not fire rebound spikes likely account for the lower $I_{\mathrm{NaP}}$ current density on diestrus versus proestrus.

We also considered the possibility that an outward current counteracts inward current from $I_{\mathrm{NaP}}$ and $I_{T}$ to decrease the burst occurrence on diestrus. Because $\mathrm{Cs}^{+}$-sensitive potassium channels likely contribute to the decreased $R_{\text {in }}$ on diestrus versus proestrus, we hypothesized that potassium currents may contribute to the silencing of bursts on diestrus for both tonic and DIB cells. In particular, we examined the 4-AP-sensitive $I_{A}$ because it can be activated at relatively hyperpolarized potentials and is thus more likely to play a role in modifying spike initiation (Perreault and Avoli, 1991; DeFazio and Moenter, 2002; Amendola et al., 2012). We performed current-clamp recordings to identify the tonic or
DIB cells that did not exhibit rebound spikes on diestrus, then treated these cells with 4-AP $(5 \mathrm{~mm})$. Of the 12 cells we tested, 5 exhibited rebound during 4-AP treatment (4 cells had one rebound spike and 1 cell had a two-spike burst; Fig. $6 B$, right). These were referred to as 4-AP-sensitive cells. The remaining seven cells did not initiate spikes upon rebound following 4-AP treatment (4-AP insensitive). Figure $6 A$ shows the representative tonic and DIB cells that were 4-AP sensitive (left) and insensitive (right). Figure $6 B$ shows that half of the tonic cells (Fig. $6 B$, left; $n=6$ ) and one-third of DIB cells (Fig. $6 B$, middle; $n=6$ ) were 4-AP sensitive. We then compared $I_{\mathrm{NaP}}$ in cells that were 4-AP sensitive $(n=5)$ and insensitive $(n=7)$, and found that current density was greater in the 4-AP-sensitive group (Fig. 6C,D; two-way RM ANOVA and Holm-Sidak test: $-47.5 \mathrm{mV}, p=0.04 ;-45 \mathrm{mV}$, $p=0.02)$. The $R_{\text {in }}$ of the tested cells increased after 4-AP treatment, which is consistent with the above change when a $\mathrm{Cs}^{+}$-based pipette solution was used (paired $t$ test, $n=11$ : control vs $4-A P, 858 \pm 72$ vs $1044 \pm 98 \mathrm{M} \Omega, p=0.005$ ). This suggests that, for a subset of neurons, potassium channels may play an active role in preventing burst generation that may be independent of the regulation of $\mathrm{I}_{\mathrm{NaP}}$ and $\mathrm{I}_{\mathrm{T}}$.

Some AVPV kisspeptin neurons are known to express hyperpolarization-activated nonselective cation channels ( $\mathrm{HCN})$ and exhibit a sag in membrane potential during current clamp typical of cells exhibiting hyperpolarizationactivated current $\left(I_{h}\right.$; Piet et al., 2013). We observed that after achieving a hyperpolarized membrane potential of $-105 \pm 3 \mathrm{mV}, 70 \%$ of AVPV kisspeptin neurons showed sag potential $(>2 \mathrm{mV})$ on diestrus $(n=29 ; 3.8 \pm 0.5 \mathrm{mV})$, and $95 \%$ on proestrus $(n=20 ; 7.3 \pm 0.7 \mathrm{mV})$. Our results confirmed that the sag potential is cycle dependent (Fig. $6 F$; Student's $t$ test, $p=0.0002$ ). To examine the role of $I_{h}$ in generating rebound bursts, we blocked HCN channels using ZD7288 (50 $\mu \mathrm{M}$; Fig. 6E). This eliminated the sag potential but did not affect the number of spikes per rebound burst for cells tested on either stage (control: 3.1 \pm 0.2 spikes/burst; ZD7288, $2.9 \pm 0.2$ spikes/burst; $p=$ 0.17 , paired Student's $t$ test; $n=9$ total, five diestrus, four proestrus), which is consistent with previous findings (Zhang et al., 2013b). This suggests that although $I_{h}$ is regulated by the estrous cycle, it may play a small role or no role in generating rebound bursts under our experimental conditions.

\section{Estrous cycle regulation of burst properties is attributable to circulating estradiol, not progesterone} The cycle-dependent changes in burst properties observed above are most likely attributed to estrous cycledependent changes in circulating levels of ovarian sex steroids, in particular estradiol and/or progesterone. To determine the role of specific gonadal steroids in these biophysical properties, we set up the following four groups of mice: $\mathrm{OVX}, \quad \mathrm{OVX}+\mathrm{E}, \quad \mathrm{OVX}+\mathrm{E}+\mathrm{P}$, and $\mathrm{OVX}+\mathrm{E}+\mathrm{V}$ to rule out the potential effects induced by injection-associated stress in $\mathrm{OVX}+\mathrm{E}+\mathrm{P}$ mice. $\mathrm{OVX}$ mice treated with $\mathrm{P}$ only were not tested because a single-cell real-time PCR scan (as in Ruka et al., 2013) of AVPV kisspeptin neurons from OVX mice indicated only 2 of 10 


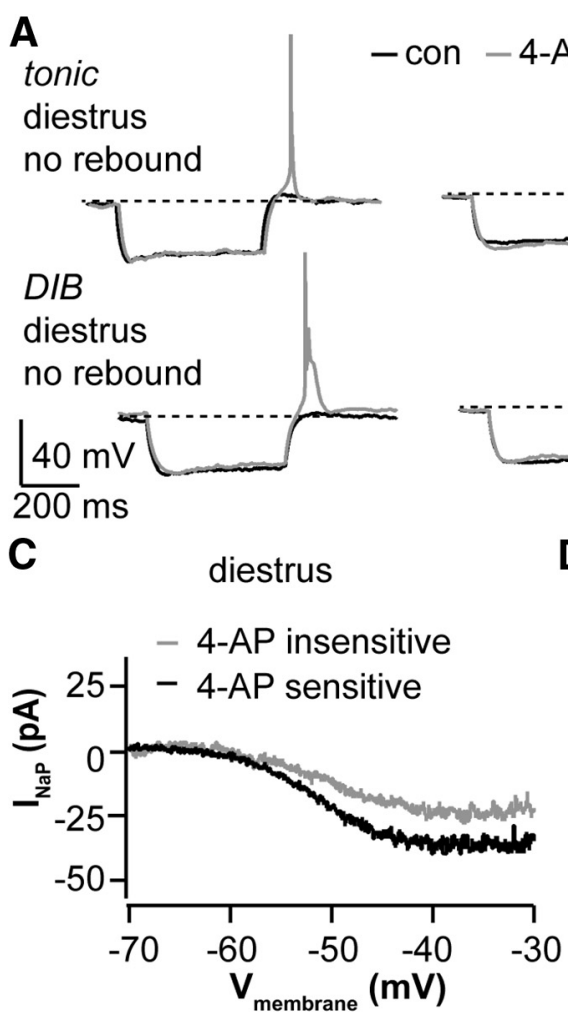

E

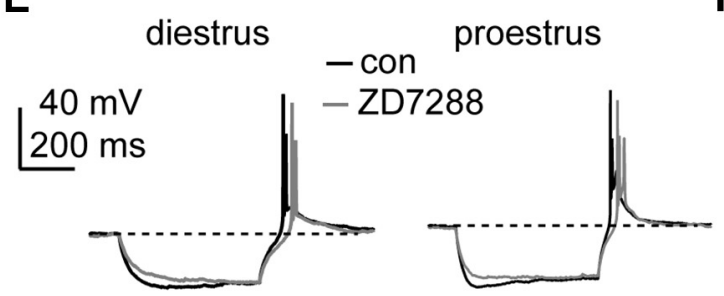

B $\mathbf{0}$ 4-AP sensitive $\square$ 4-AP insensitive

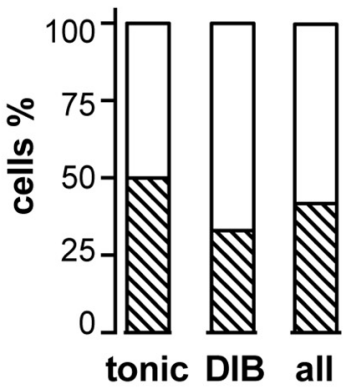

D
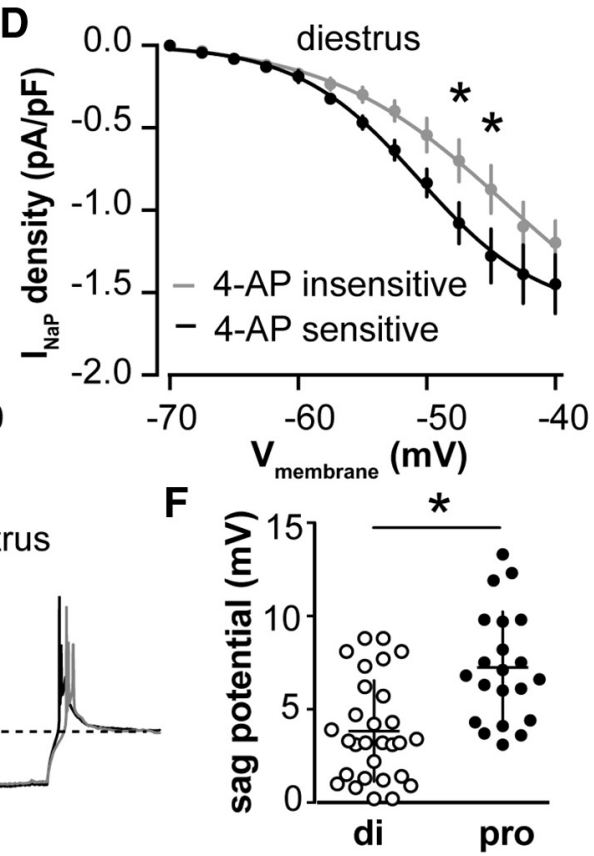

Figure 6. Subpopulations of cells that exhibit no rebound spikes on diestrus have restored ability to generate rebound spikes after blocking $\mathrm{I}_{\mathrm{A}}$. $\boldsymbol{A}$, Representative firing properties of tonic and DIB cells on diestrus that did not exhibit rebound spikes under control conditions (black): 4-AP (5 mM) treatment (gray) restored rebound spikes in some cells (left) but not others (right). $\boldsymbol{B}$, Percentage of cells with 4-AP-sensitive (hatched bar) or 4-AP-insensitive rebound firing (open bar) for tonic, DIB, and all cells combined on diestrus. C, Representative $\mathrm{I}_{\mathrm{NaP}}$ in 4-AP-sensitive (black) and 4-AP-insensitive (gray) cells tested on diestrus. $\boldsymbol{D}, \mathrm{Mean}^{ \pm} \mathrm{SEM} \mathrm{I}_{\mathrm{NaP}}$ current density for 4-AP-sensitive (black) and 4-AP-insensitive (gray) cells tested on diestrus. $* p<0.05$ calculated by two-way RM ANOVA and Holm-Sidak test. $\boldsymbol{E}$, Representative cells on diestrus and proestrus preserved rebound bursts but not sag potential after ZD7288 $(50 \mu \mathrm{M})$ application. $\boldsymbol{F}$, Sag potential was increased on proestrus compared to diestrus. $* p<0.05$, Student's $t$ test.

cells expressed the estrogen-dependent progesterone receptor mRNA three days after ovariectomy, compared to 7 of 9 cells from OVX mice treated with estradiol (not shown).

Short-term firing patterns of AVPV kisspeptin neurons were monitored (Fig. 1) in all four groups of mice (OVX, $\mathrm{OVX}+\mathrm{E}, \mathrm{OVX}+\mathrm{E}+\mathrm{V}$, and $\mathrm{OVX}+\mathrm{E}+\mathrm{P}$ ) via extracellular recordings with antagonized AMPA, NMDA, and $\mathrm{GABA}_{\mathrm{A}}$ receptors. There were no differences in firing rate or bursts between $\mathrm{OVX}+\mathrm{E}$ and $\mathrm{OVX}+\mathrm{E}+\mathrm{V}$ mice when we compared all four groups (one-way ANOVA with Bonferroni correction, $p>0.99$ ), indicating that injection alone causes no detectable change in the firing properties in AVPV kisspeptin neurons. OVX $+E$ and $\mathrm{OVX}+\mathrm{E}+\mathrm{V}$ cells were thus combined for burst analyses and are reported as $\mathrm{OVX}+\mathrm{E}$ in Figure 7, $B$ and $C$; vehicle-treated animals were not included in further studies. Firing frequency in $\mathrm{OVX}+\mathrm{E}$ and $\mathrm{OVX}+\mathrm{E}+\mathrm{P}$ cells was increased compared with OVX cells ( $p<0.0001$ and $p<0.02$, respectively), whereas no difference was observed between $\mathrm{OVX}+\mathrm{E}+\mathrm{P}$ and $\mathrm{OVX}+\mathrm{E}$ cells (Fig. 7A,B; one-way ANOVA with Bonferroni correction). Spontaneous bursting events were increased in cells from OVX+E and OVX mice (Fig. 7C; one-way ANOVA with KW/Dunn's test, $p=0.03$ ). The number of bursts in cells from OVX $+E+P$ mice was intermediate to and not different from that in cells from either $\mathrm{OVX}$ or $\mathrm{OVX}+\mathrm{E}$ mice. These observations suggest that estradiol alters the firing frequency and pattern of AVPV 

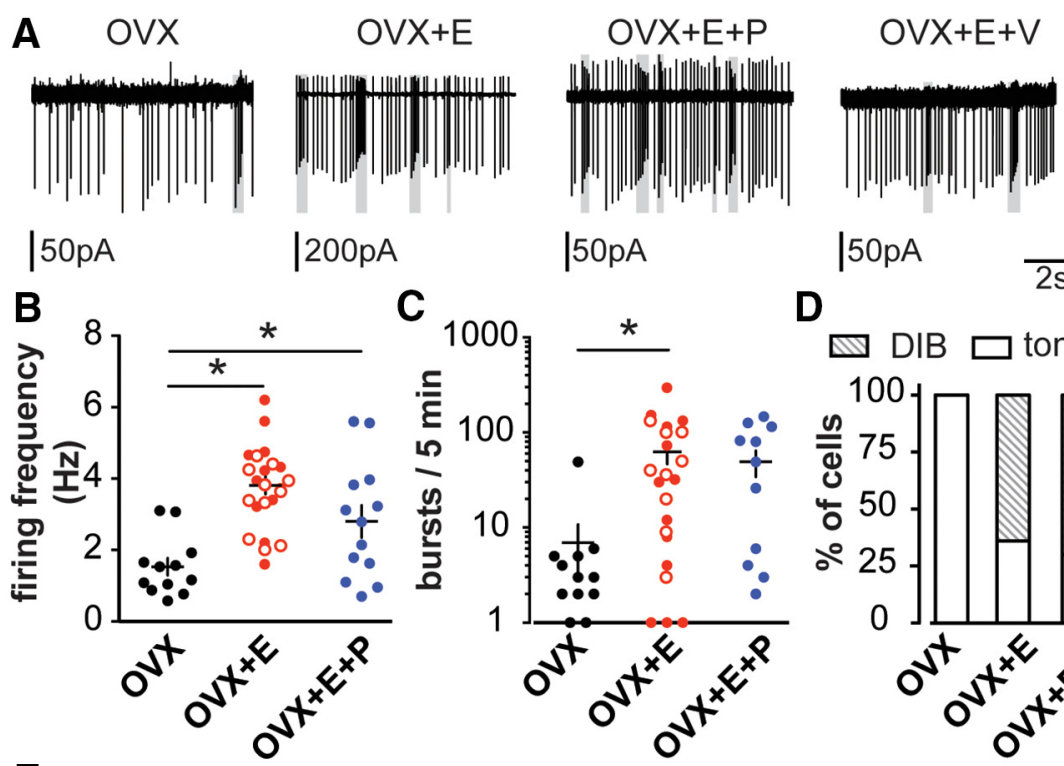

I50pA

D DIB $\square$ tonic

E

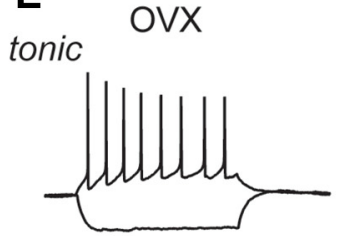

tonic

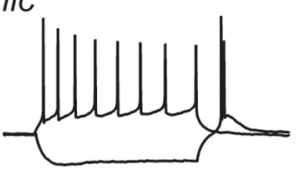

$D I B$

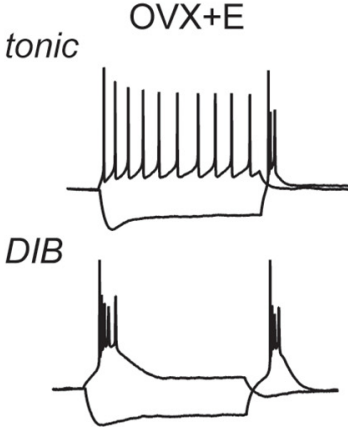

tonic

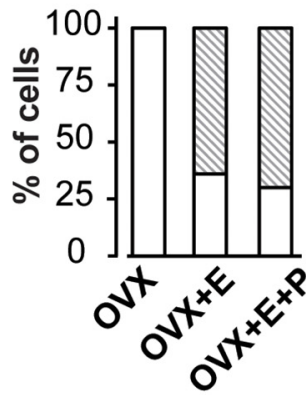

$\mathbf{F}$

G
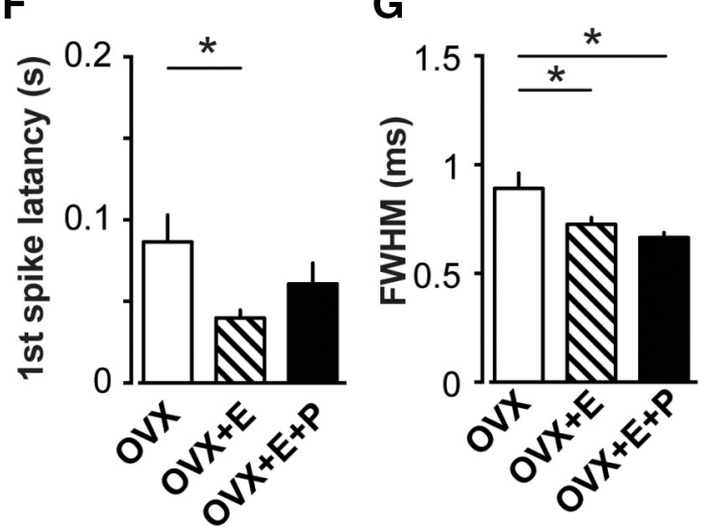

H

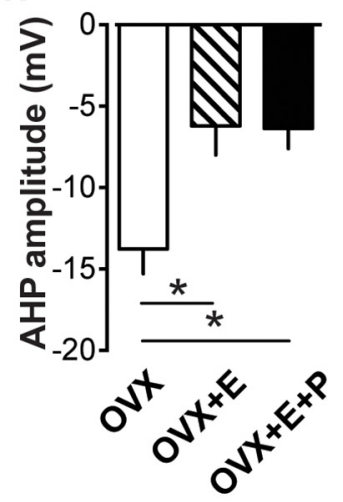

Figure 7. Estradiol but not progesterone increases overall excitability and burst events in AVPV kisspeptin neurons. $\boldsymbol{A}$, Representative extracellular recordings of $\mathrm{OVX}, \mathrm{OVX}+\mathrm{E}, \mathrm{OVX}+\mathrm{E}+\mathrm{P}$, and $\mathrm{OVX}+\mathrm{E}+\mathrm{V}$ with $\mathrm{AMPA}, \mathrm{NMDA}$, and GABA $\mathrm{A}_{\mathrm{A}}$ receptors antagonized. Gray boxes indicate bursts. $\boldsymbol{B}, \boldsymbol{C}$, Mean \pm SEM firing frequency $(\boldsymbol{B})$ and number of burst events $(\boldsymbol{C})$ of OVX (black circles), OVX+E (solid red circles), $\mathrm{OVX}+\mathrm{E}+\mathrm{V}$ (open red circles), and OVX $+\mathrm{E}+\mathrm{P}$ (blue). $\boldsymbol{D}$, Percentage of cells that fire DIB or tonic patterns on OVX, OVX+E, and $\mathrm{OVX}+\mathrm{E}+\mathrm{P}$ groups. $\boldsymbol{E}$, Representative firing properties of tonic (top) and DIB (bottom; except OVX) cells in OVX, OVX+E, and OVX $+E+P$ groups. $\boldsymbol{F}-\boldsymbol{H}$, Mean \pm SEM of action potential parameters in OVX (white), OVX $+E$ (hatched), and OVX $+E+P$ (black) groups: latency to first spike $(\boldsymbol{F})$, action potential FWHM $(\boldsymbol{G})$, and AHP potential (amplitude; $\boldsymbol{H})$. $* p<0.05$ calculated by one-way ANOVA/Bonferroni test or Kruskal-Wallis or Dunn's test, as dictated by data distribution.

kisspeptin neurons, and that the addition of progesterone does not appear to further shift these parameters.

To examine steroid effects on action potential properties, whole-cell recordings were used to capture the firing signature of AVPV kisspeptin neurons in OVX, OVX+E, and $\mathrm{OVX}+\mathrm{E}+\mathrm{P}$ groups in response to the depolarization and removal of hyperpolarization (Fig. 7E). Most cells from $\mathrm{OVX}+\mathrm{E}$ mice $(64 \%, n=7$ of 11$)$ and $\mathrm{OVX}+\mathrm{E}+\mathrm{P}$ mice $(67 \%, 6$ of 9) exhibit DIBs. In contrast, DIBs were not observed in cells from OVX mice, and all cells from these 


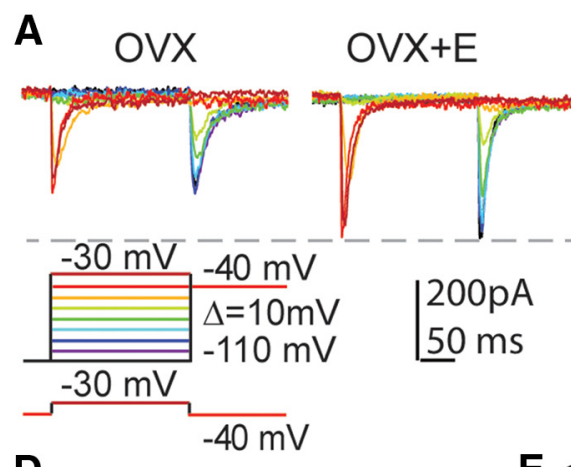

D

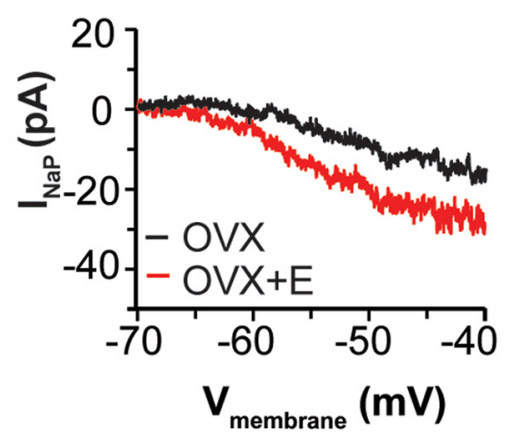

B - OVX - OVX+E C
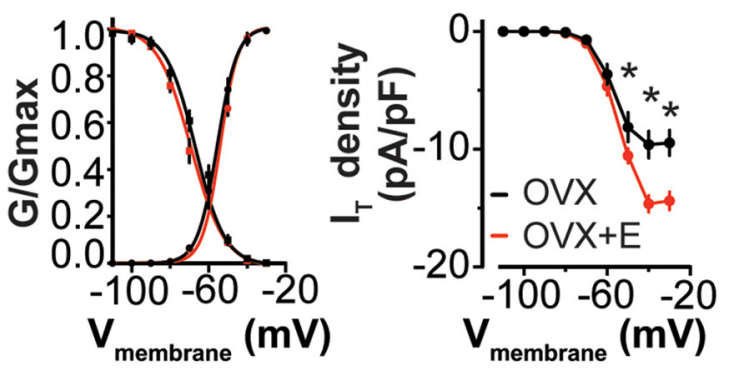

E

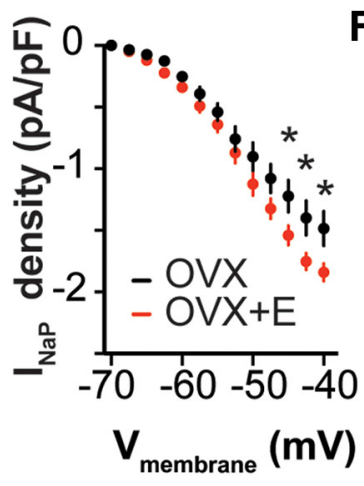

$\mathbf{F}$

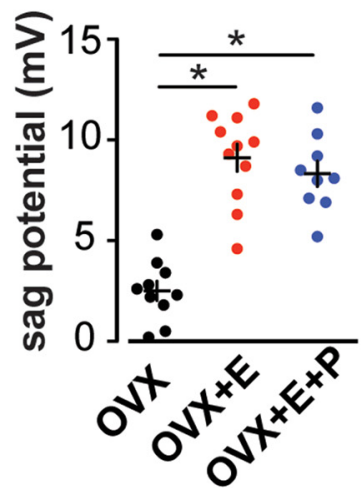

Figure 8. Estradiol increases $I_{\mathrm{T}}$ and $I_{\mathrm{NaP}}$ density in AVPV kisspeptin neurons. $\boldsymbol{A}$, Voltage protocol (bottom) and representative subtraction-isolated $I_{\mathrm{T}}$ in OVX (top left) and OVX $+\mathrm{E}$ groups (top right). $\boldsymbol{B}$, Activation and inactivation of $I_{\mathrm{T}}$ conductance was plotted and fit with a Boltzmann function to derive $V_{1 / 2}$ and $k$ value in OVX (black) and OVX $+E$ (red). C, Mean \pm SEM current density of $I_{\mathrm{T}}$ in OVX (black) and OVX+E (red). $\boldsymbol{D}$, Representative $I_{\mathrm{NaP}}$ in OVX (black) and OVX+E (red) groups. $\boldsymbol{E}$, Mean $\pm \mathrm{SEM} I_{\mathrm{NaP}}$ density in OVX (black) vs OVX+E (red) groups. $\boldsymbol{F}$, Mean \pm SEM of sag potential induced by hyperpolarization. $* p<0.05$ calculated by two-way RM ANOVA/Holm-Sidak test for $\boldsymbol{D}$ and $\boldsymbol{E} ; * p<0.05$ calculated by one-way ANOVA/Bonferroni test for $\boldsymbol{F}$.

mice fired in a tonic manner upon depolarization (Fig. 7D; $n=10 ; \chi^{2}$ test, $p=0.003$ ). In response to the removal of hyperpolarization, more cells fire rebound bursts in the $\mathrm{OVX}+\mathrm{E}$ and $\mathrm{OVX}+\mathrm{E}+\mathrm{P}$ groups than in the $\mathrm{OVX}$ group: only $30 \%$ of OVX cells $(3$ of 10$)$ fire rebound bursts, whereas $\sim 90 \%$ of $O V X+E$ cells $(10$ of 11$)$ and $O V X+E+P$ cells $(8$ of 9$)$ fire rebound bursts $\left(\chi^{2}\right.$ test, $\left.p=0.003\right)$. The number of spikes in rebound bursts was increased in cells from OVX $+\mathrm{E}$ mice $(4.7 \pm 0.9, n=11)$ compared with OVX $(0.9 \pm 0.3, n=10$; one-way ANOVA with Bonferroni correction, OVX vs $\mathrm{OVX}+\mathrm{E}$ mice, $p=0.0007)$. This parameter had an intermediate value in cells from $\mathrm{OVX}+\mathrm{E}+\mathrm{P}$ mice $(2.9 \pm 0.5 ; n=9)$. The latency to the first spike was decreased in cells from OVX $+E$ versus OVX mice $(p=0.02)$; again this parameter had an intermediate value in cells from $\mathrm{OVX}+\mathrm{E}+\mathrm{P}$ mice (Fig. $7 F$ ). FWHM and AHP amplitude were increased in cells from both $\mathrm{OVX}+\mathrm{E}$ and $\mathrm{OVX}+\mathrm{E}+\mathrm{P}$ mice compared with those observed in OVX mice (Fig. 7G, H; Table 3).

We also examined the effects of estradiol on the modulation of $\mathrm{I}_{\mathrm{T}}$ and $\mathrm{I}_{\mathrm{NaP}}$, as detailed above. Estradiol increased $I_{\mathrm{T}}$ current density (Fig. 8A,C; OVX, $n=10$; $\mathrm{OVX}+\mathrm{E}, n=10$; two-way RM ANOVA and Holm-Sidak test: $-50 \mathrm{mV}, p=0.04 ;-40 \mathrm{mV}, p<0.001 ;-30 \mathrm{mV}, p$ $<0.001$ ) as well as $I_{\mathrm{NaP}}$ current density (Fig. $8 D, E ;$ OVX, $n$ $=10$; OVX $+\mathrm{E}, n=11$; two-way RM ANOVA and HolmSidak test: $-50 \mathrm{mV}, p=0.02 ;-45 \mathrm{mV}, p=0.01 ;-40$ $\mathrm{mV}, p=0.01$ ). Similar to the lack of change in voltage- dependent activation and inactivation of $\mathrm{I}_{\mathrm{T}}$ between diestrous and proestrous phases of the estrous cycle, estradiol did not affect these parameters (Fig. 8B; activation, $n=10$ each: $V_{1 / 2}$ : OVX, $-55.3 \pm 1.2 ; \mathrm{OVX}+\mathrm{E},-54.0$ $\pm 1.0 ; p=0.41$; slope factor $k$ : OVX, $5.6 \pm 0.5 ; \mathrm{OVX}+\mathrm{E}$, $5.3 \pm 0.4 ; p=0.51$; inactivation, $n=10$ each: $V_{1 / 2}$ : OVX, $-66.3 \pm 1.3$; OVX+E, $-69.1 \pm 1.5 ; p=0.09$; slope factor $\mathrm{k}$ : OVX, $-3.3 \pm 0.2 ; \mathrm{OVX}+\mathrm{E},-3.3 \pm 0.2 ; p=0.80$, Student's $t$ test). The sag potential, which represents the activation of the HCN channel at the hyperpolarized potential, was increased in cells in the $\mathrm{OVX}+\mathrm{E}$ and $\mathrm{OVX}+\mathrm{E}+\mathrm{P}$ groups compared with that observed in the OVX group (Fig. 8F; one-way ANOVA with Bonferroni correction, $\mathrm{OVX}+\mathrm{E}$ vs $\mathrm{OVX}$ and $\mathrm{OVX}+\mathrm{E}+\mathrm{P}$ vs $\mathrm{OVX}, p<$ $0.0001)$. These observations suggest that most cycledependent effects on AVPV kisspeptin neuron firing and associated currents are attributable to estradiol.

\section{Discussion}

Steroid milieu and other cues are integrated to generate a $\mathrm{GnRH}$ release pattern as the central output signal controlling fertility. In most vertebrates, estradiol-positive feedback induces a surge of $\mathrm{GnRH}$ release that is crucial for ovulation (Moenter et al., 1992; Christian and Moenter, 2010). GnRH neurons receive estradiol feedback mainly via steroid-sensitive afferents, including AVPV kisspeptin neurons (Pinilla et al., 2012). We demonstrated AVPV kisspeptin neurons increase overall and burst firing rate 


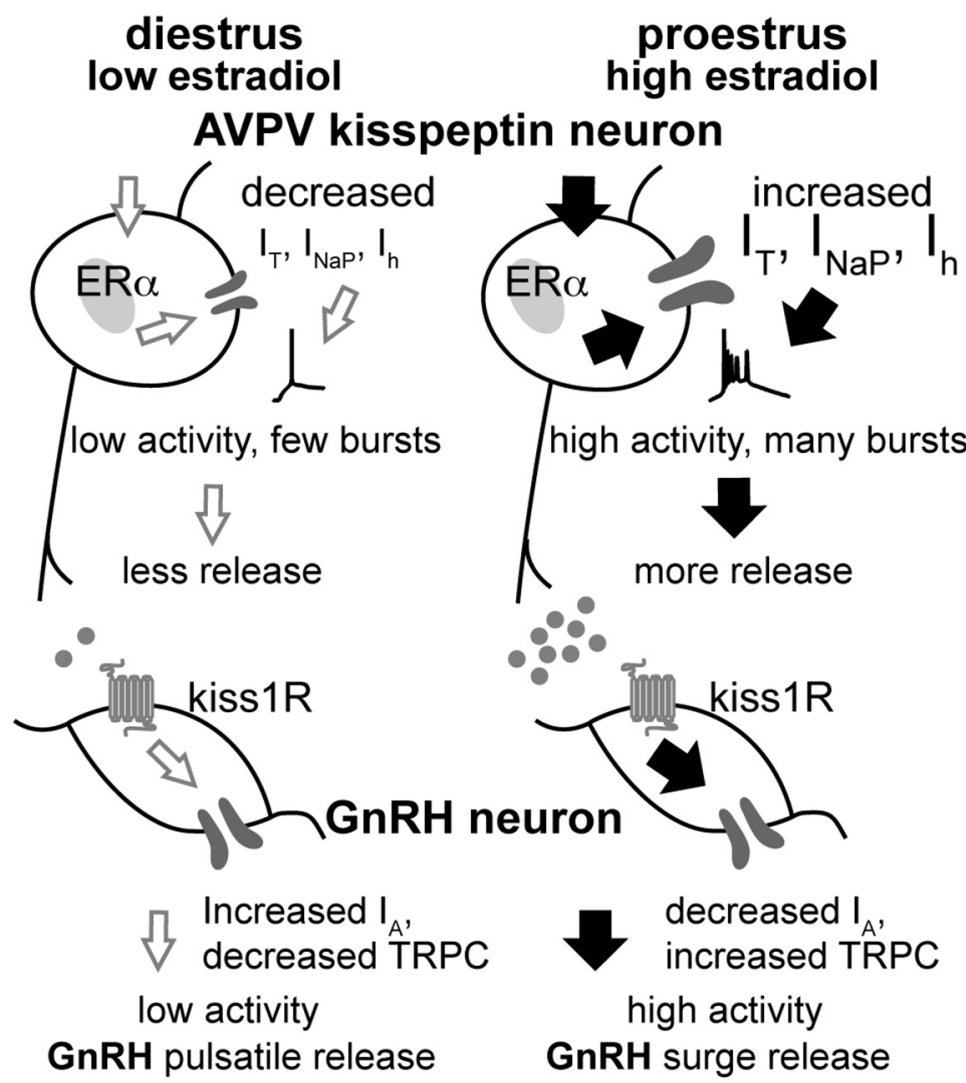

Figure 9. Schematic model of cyclic regulation of the AVPV kisspeptin-GnRH circuitry. On diestrus, low estradiol levels exert negative feedback and AVPV kisspeptin neurons exhibit low $I_{T}, I_{\mathrm{NaP}}$, and $\mathrm{I}_{\mathrm{h}}$. This contributes to reduced overall and burst firing, thus lower release of kisspeptin, GABA, and glutamate. GnRH neurons exhibit low activity and a pulsatile release pattern. On proestrus, high levels of estradiol exert positive feedback action, increasing $I_{\mathrm{T}} I_{\mathrm{NaP}}$, and $I_{\mathrm{h}}$, and facilitate increased overall excitability and, for the former two currents, increase burst firing. This increases neurosecretion from these neurons, increasing excitatory drive to $\mathrm{GnRH}$ neurons via kisspeptin, GABA, and glutamate, and also increasing $\mathrm{GnRH}$ neuron activity via kisspeptin-mediated reduction of $\mathrm{I}_{\mathrm{A}}$ (Pielecka-Fortuna et al., 2011) and increase in TRPC (transient receptor potential canonical) conductance (Zhang et al., 2013a). Together, the intrinsic changes and increased excitatory drive provoke increased release of GnRH (Glanowska et al., 2012).

on proestrus versus diestrus, and revealed the estrous cycle regulates the interactions of multiple conductances contributing to burst generation primarily via cycledependent changes in circulating estradiol levels (Fig. 9).

Burst firing is implicated in the increasing reliability of neural information processing, synaptic plasticity, and neuropeptide/neuroendocrine secretion (Krahe and Gabbiani, 2004; van den Pol, 2012). For the latter, increased cytoplasmic calcium induced by bursts may enhance dense-core vesicle fusion with the plasma membrane (Jackson et al., 1991; Muschol and Salzberg, 2000). Shifts toward increased AVPV kisspeptin neuron firing frequency and burst events may thus indicate increased neurosecretion.

All AVPV kisspeptin neurons examined were spontaneously active, but activity was greater on proestrus. The increased activity of AVPV kisspeptin neurons from proestrous and $\mathrm{OVX}+\mathrm{E}$ mice is consistent with elevated cFos expression in this cell population during the preovulatory or estradiol-induced LH surge (Smith et al., 2006; Clarkson et al., 2008). Of note, other studies (Ducret et al., 2010; De Croft et al., 2012; Piet et al., 2015) found no cycle-dependent shift in the spontaneous firing rate of AVPV kisspeptin neurons, with reports of trends toward either increased or decreased activity on proestrus. This contrast may in part be attributable to methodological differences, including slice thickness, recording duration, and the time of day of the experiment. Activity of the reproductive neuroendocrine circuitry, particularly that involved in estradiol-positive feedback, is regulated by the time of day (Christian and Moenter, 2010). Slices in the present study were prepared at zeitgeber time 10 (ZT10) to $Z T 11$, at the peak of the reported increase in the expression of cFos in AVPV kisspeptin neurons in OVX $+E$ mice (ZT9 to ZT12; Robertson et al., 2009; Kriegsfeld, 2013), whereas previous studies were conducted from ZT4 to ZT6. Notably, the firing frequency of AVPV kisspeptin neurons in the present study increased by $\sim 20$ $30 \%$ after an 8-10 min stable recording, limiting confidence in the analysis of longer-term firing patterns.

Burst firing may be attributable to intrinsic mechanisms and/or synaptic inputs. AVPV kisspeptin neurons receive glutamate and GABA synaptic inputs (Frazão et al., 2013), the latter of which is known to be regulated by both time 
of day and estradiol (DeFazio et al., 2014). Blocking fast synaptic transmission reduced, but did not eliminate, burst firing in the present study, suggesting that intrinsic mechanisms contribute to bursts. Although a role for other transmitters/peptides in AVPV kisspeptin neuron burst generation cannot be eliminated, we focused on the intrinsic ionic conductances underlying firing and burst generation.

AVPV kisspeptin neurons were classified as tonic or DIB neurons based on firing patterns evoked by depolarizing these cells from their baseline membrane potential. Both tonic and DIB cells exhibited rebound bursts induced by hyperpolarization termination. The percentage of cells exhibiting DIB and rebound bursts was increased by estradiol (OVX vs OVX+E mice), with rebound bursts also increasing on proestrus versus diestrus. Importantly, we observed cells in slices from the same diestrous mouse that both fire and fail to exhibit rebound bursts. This suggests that these differences are unlikely to be attributed to different steroid levels in vivo. One postulate is that the difference in rebound burst firing in cells on diestrus is related to the expression of ER $\alpha$, which may affect the ionic conductance profiles and firing patterns. Of interest, the percentage of AVPV kisspeptin neurons expressing $\mathrm{ER} \alpha$ is $\sim 65 \%$ (Clarkson et al., 2008; Mayer et al., 2010) versus $\sim 60 \%$ of cells on diestrus exhibiting no rebound burst properties. This increase in elicited bursts was consistent with increased spontaneous firing during both experimentally induced or cycle-dependent elevation of estradiol. Together, these studies suggest depolarization and release from hyperpolarization as two possible mechanisms for generating the spontaneous bursts observed in extracellular recordings. DIB was not observed in the absence of ovarian-derived estradiol, indicating a critical role for this steroid in generating closely spaced spikes upon depolarization. Our results add new, functional parameters to classify AVPV kisspeptin neurons. Future studies will focus on combining the electrophysiological properties with molecular signatures to uncover the specific roles that each cellular subtype may perform.

The distinct action potential signatures of tonic and DIB patterns suggest that different channel types may be contributing to action potential firing in these cells (Bean, 2007). We next began to decipher the ionic conductances underlying firing properties in tonic and DIB cells. The presence of currents at subthreshold membrane potentials can enhance or retard spike generation to influence the overall firing patterns in many brain regions (DeFazio and Moenter, 2002; Puopolo et al., 2007; Chu et al., 2010; Itri et al., 2010; Khaliq and Bean, 2010), including AVPV kisspeptin neurons (Zhang et al., 2013b, 2015). In the present study, the sensitivity of depolarization-induced bursting to $\mathrm{Ni}^{2+}$ and initial membrane potential further suggests that this firing pattern may arise from conductances that are voltage dependent and/or $\mathrm{Ni}^{2+}$ sensitive. Rebound bursts were also $\mathrm{Ni}^{2+}$ sensitive. Further, the positive correlation between rebound depolarization when firing was blocked and the instantaneous frequency of rebound bursts further suggests that $\mathrm{I}_{\mathrm{T}}$ may also be im- portant to rebound burst generation. Of note, no such correlation was observed in DIB cells; this may be attributed to a higher potassium conductance near the baseline potential opposing the action of $\mathrm{I}_{\mathrm{T}}$.

Because $\mathrm{Ni}^{2+}$ is not a complete or exclusive blocker of $\mathrm{I}_{\mathrm{T}}$, and it is difficult to attribute the role of a specific conductance to observations in current-clamp recordings, voltage clamp was used to isolate $\mathrm{I}_{\mathrm{T}}$. The biophysical parameters of $I_{T}$ in AVPV kisspeptin neurons in the present study are consistent with the parameters measured in other neuronal population (Molineux et al., 2005; Talavera and Nilius, 2006; Nelson et al., 2007). The increased current density on proestrus and in cells from $\mathrm{OVX}+\mathrm{E}$ mice in the absence of shifts in voltage dependence suggests that an increased number of channels in the membrane may contribute to increased bursting. Interestingly, $I_{T}$ current density differed at physiologically relevant membrane potentials critical for spike generation. Questions remain about whether tonic and DIB cells have distinct $\mathrm{I}_{\mathrm{T}}$ current densities because firing properties are difficult to determine with the $\mathrm{Cs}^{+}$-based pipette solution used to quantify $\mathrm{I}_{\mathrm{T}}$

Interestingly, all the cells tested on diestrus exhibited $\mathrm{I}_{\mathrm{T}}$, raising the question of why only half of these cells exhibit rebound bursts. The latter may be attributable to a decreased depolarizing conductance and/or an increased hyperpolarizing conductance in cells without rebound bursts. We targeted $I_{\mathrm{NaP}}, \mathrm{I}_{\mathrm{h}}$, and $\mathrm{I}_{\mathrm{A}}$ to test this postulate because of their activation at subthreshold membrane potentials. Previous studies show that $I_{\mathrm{NaP}}$ density in AVPV kisspeptin neurons was increased in mice treated with high estradiol versus low estradiol levels (Zhang et al., 2015). We found that both $I_{\mathrm{NaP}}$ and $\mathrm{I}_{\mathrm{A}}$ currents may sculpt burst firing in AVPV kisspeptin neurons. The lack of specific $I_{\mathrm{NaP}}$ blockers precludes parsing its role compared with that of $\mathrm{I}_{\mathrm{T}}$ in generating rebound bursts, but the upregulation of $I_{\mathrm{NaP}}$ upon specific manipulation of estradiol suggests that this steroid plays a role in the cycledependent changes observed. Cells that did not fire rebound bursts had decreased $I_{\mathrm{NaP}}$ relative to cells that fired rebound bursts in diestrous mice. These observations suggest that interactions among various currents alter burst firing. Blocking $I_{A}$ permitted rebound spikes in half of the cells recorded on diestrus regardless of their depolarization-evoked firing pattern. Interestingly, $I_{\mathrm{NaP}}$ was also different between 4-AP-sensitive and 4-APinsensitive cells near the action potential threshold, suggesting that the increased persistent sodium current in the 4-AP-sensitive group may be able to influence burst firing with the removal of $\mathrm{I}_{A}$. In the 4-AP-insensitive group, the removal of $I_{A}$ did not lead to rebound bursts, suggesting that a relatively small $I_{\mathrm{T}}$ and/or $I_{\mathrm{NaP}}$ is not able to evoke rebound spikes. In the present studies, blocking the $I_{h}$ did not affect burst firing induced by current injections during the reproductive cycle. This current may still play a role in spontaneous bursting in these neurons via interactions with other conductances activated at subthreshold potentials. In this regard, other studies have not found an effect of blocking $I_{\mathrm{h}}$ on firing rate during proestrus, although an increase in spike latency was observed (Piet et al., 2013; 
Zhang et al., 2013b). Our results suggest an interaction among two transient currents $\left(\mathrm{I}_{T}\right.$ and $\left.\mathrm{I}_{\mathrm{A}}\right)$ and one persistent current $\left(I_{\mathrm{NaP}}\right)$ that may modulate the bursting generation in AVPV kisspeptin neuronal population, supporting and extending previous work (Zhang et al., 2015). Furthermore, potassium currents also appear to play a role in regulating passive membrane properties by increasing the input resistance on proestrus compared to diestrus. This may result in an increased gain of the cells to respond to their afferent stimulus.

These observations are consistent with the increasing understanding through experimental and computational studies that different interactions among ionic conductances can generate the same firing properties in many neurons across species (Goldman et al., 2001; Puopolo et al., 2007). Neurons can achieve similar firing output by adding, deleting, or modulating different conductances (Prinz et al., 2004; Swensen and Bean, 2005). In AVPV kisspeptin neurons, the present results indicate that bursts can be generated via depolarization or release of hyperpolarization, both of which may recruit multiple ionic conductances. Bursts may be triggered and facilitated by increased $\mathrm{I}_{\mathrm{T}}, \mathrm{I}_{\mathrm{NaP}}$, or decreased $\mathrm{I}_{\mathrm{A}}$; and they may be silenced or reduced (e.g., number of events and frequency) with a combination of decreased $\mathrm{I}_{\mathrm{T}}$ and $\mathrm{I}_{\mathrm{NaP}}$, and increased $I_{A}$. In a cell type that is likely critical to reproduction, the ability to produce the appropriate output via a variety of scenarios is pertinent to the survival of the species.

Another question is which cycle-dependent cues are responsible for the regulation of multiple ionic conductances. In the present study, we recorded at a consistent time of day to control the diurnal input to AVPV kisspeptin neurons. One prominent difference between cycle stages is the sex steroid milieu, especially estradiol, which regulates kisspeptin mRNA and cFos expression (Smith et al., 2006). Specific steroid manipulations suggest a dominant role for estradiol in increased current density of $I_{\mathrm{T}}, I_{\mathrm{h}}$, and $I_{\mathrm{NaP}}$, adding strong mechanistic support for estradiol regulation of AVPV kisspeptin neuron firing (Kumar et al., 2015). Estradiol may act through genomic mechanisms to change ion channel expression or function. For example, high estradiol treatment increased the relative levels of $\mathrm{Ca}_{\mathrm{v}}$ 3.1 mRNA expression compared with low-estradiol treatment in pools of isolated AVPV kisspeptin neurons (Zhang et al., 2015), although the question remains of whether more cells are expressing $\mathrm{Ca}_{\mathrm{v}} 3.1$ mRNA or the cells increased $\mathrm{Ca}_{v} 3.1$ mRNA overall. Additionally, estradiol may function via membrane-associated mechanisms to induce post-translational modifications of ion channels or insertion/removal into/from the membrane (Morissette et al., 2008; Vasudevan and Pfaff, 2008). Recently, a genetic tracing approach suggested that only AVPV kisspeptin neurons express the ER $\alpha$ synapse on GnRH neurons (Kumar et al., 2015), further supporting the postulate of an estradiol-kisspeptin-GnRH feedback loop.

In summary, our findings demonstrate that increased firing rate and burst events in AVPV kisspeptin neurons on proestrus versus diestrus likely result from cycledependent changes in estradiol modifying multiple con- ductances. Burst generation may be attributed to the interplay of intrinsic properties with both excitatory input and release from inhibition. Our results support previous observations and extend these by focusing on the regulation of the interactions among intrinsic properties in generating the electrophysiological output of AVPV kisspeptin neurons. The changes in this output associated with the shift between estradiol-negative and estradiolpositive feedback actions likely play an important role in female fertility.

\section{References}

Alcami P, Franconville R, Llano I, Marty A (2012) Measuring the firing rate of high-resistance neurons with cell-attached recording. $J$ Neurosci 32:3118-3130. CrossRef Medline

Amendola J, Woodhouse A, Martin-Eauclaire M-F, Goaillard J-M (2012) $\mathrm{Ca}^{2+} /$ CAMP-sensitive covariation of $I_{\mathrm{A}}$ and $I_{\mathrm{H}}$ voltage dependences tunes rebound firing in dopaminergic neurons. J Neurosci 32:2166-2181. CrossRef

Andrews WW, Mizejewski GJ, Ojeda SR (1981) Development of estradiol-positive feedback on luteinizing hormone release in the female rat: a quantitative study. Endocrinology 109:1404-1413. CrossRef Medline

Barry PH (1994) JPCalc, a software package for calculating liquid junction potential corrections in patch-clamp, intracellular, epithelial and bilayer measurements and for correcting junction potential measurements. J Neurosci Methods 51:107-116. Medline

Bean BP (2007) The action potential in mammalian central neurons. Nat Rev Neurosci 8:451-465. CrossRef Medline

Christian CA, Moenter SM (2010) The neurobiology of preovulatory and estradiol-induced gonadotropin-releasing hormone surges. Endocr Rev 31:544-577. CrossRef Medline

Christian CA, Mobley JL, Moenter SM (2005) Diurnal and estradioldependent changes in gonadotropin-releasing hormone neuron firing activity. Proc Natl Acad Sci U S A 102:15682-15687. CrossRef Medline

Christian CA, Glidewell-Kenney C, Jameson JL, Moenter SM (2008) Classical estrogen receptor $\alpha$ signaling mediates negative and positive feedback on gonadotropin-releasing hormone neuron firing. Endocrinology 149:5328-5334. CrossRef Medline

Chu Z, Takagi H, Moenter SM (2010) Hyperpolarization-activated currents in gonadotropin-releasing hormone ( $\mathrm{GnRH})$ neurons contribute to intrinsic excitability and are regulated by gonadal steroid feedback. J Neurosci 30:13373-13383. CrossRef Medline

Clarkson J, d'Anglemont de Tassigny X, Moreno AS, Colledge WH, Herbison AE (2008) Kisspeptin-GPR54 signaling is essential for preovulatory gonadotropin-releasing hormone neuron activation and the luteinizing hormone surge. J Neurosci 28:8691-8697. CrossRef

Couse JF, Hewitt SC, Bunch DO, Sar M, Walker VR, Davis BJ, Korach KS (1999) Postnatal sex reversal of the ovaries in mice lacking estrogen receptors alpha and beta. Science 286:23282331. CrossRef

Cravo RM, Margatho LO, Osborne-Lawrence S, Donato J, Jr., Atkin S, Bookout AL, Rovinsky S, Frazao R, Lee CE, Gautron L, Zigman JM, Elias CF (2011) Characterization of Kiss1 neurons using transgenic mouse models. Neuroscience 173:37-56.

De Croft S, Piet R, Mayer C, Mai O, Boehm U, Herbison AE (2012) Spontaneous kisspeptin neuron firing in the adult mouse reveals marked sex and brain region differences but no support for a direct role in negative feedback. Endocrinology 153:5384-5393. CrossRef Medline

DeFazio RA, Moenter SM (2002) Estradiol feedback alters potassium currents and firing properties of gonadotropin-releasing hormone neurons. Mol Endocrinol 16:2255-2265. CrossRef Medline

DeFazio RA, Heger S, Ojeda SR, Moenter SM (2002) Activation of A-type gamma-aminobutyric acid receptors excites gonadotropin- 
releasing hormone neurons. Mol Endocrinol 16:2872-2891. CrossRef Medline

DeFazio RA, Elias CF, Moenter SM (2014) GABAergic transmission to kisspeptin neurons is differentially regulated by time of day and estradiol in female mice. J Neurosci 34:16296-16308. CrossRef Medline

Dror T, Franks J, Kauffman AS (2013) Analysis of multiple positive feedback paradigms demonstrates a complete absence of $\mathrm{LH}$ surges and $\mathrm{GnRH}$ activation in mice lacking kisspeptin signaling. Biol Reprod 88:146. CrossRef Medline

Dubois SL, Acosta-Martínez M, DeJoseph MR, Wolfe A, Radovick S, Boehm U, Urban JH, Levine JE (2015) Positive, but not negative feedback actions of estradiol in adult female mice require estrogen receptor $\alpha$ in kisspeptin neurons. Endocrinology 156:1111-1120. CrossRef

Ducret E, Gaidamaka G, Herbison AE (2010) Electrical and morphological characteristics of anteroventral periventricular nucleus kisspeptin and other neurons in the female mouse. Endocrinology 151:2223-2232. CrossRef Medline

Frazão R, Cravo RM, Donato J, Ratra D V., Clegg DJ, Elmquist JK, Zigman JM, Williams KW, Elias CF (2013) Shift in Kiss1 cell activity requires estrogen receptor. J Neurosci 33:2807-2820. CrossRef Medline

Gallo R V, Bona-Gallo A (1985) Lack of ovarian steroid negative feedback on pulsatile luteinizing hormone release between estrus and diestrous day 1 in the rat estrous cycle. Endocrinology 116: 1525-1528. CrossRef Medline

Gaskins GT, Moenter SM (2012) Orexin A suppresses gonadotropinreleasing hormone $(\mathrm{GnRH})$ neuron activity in the mouse. Endocrinology 153:3850-3860. CrossRef Medline

Glanowska KM, Venton BJ, Moenter SM (2012) Fast scan cyclic voltammetry as a novel method for detection of real-time gonadotropin-releasing hormone release in mouse brain slices. $J$ Neurosci 32:14664-14669. CrossRef Medline

Goldman MS, Golowasch J, Marder E, Abbott LF (2001) Global structure, robustness, and modulation of neuronal models. J Neurosci 21:5229-5238. Medline

Han S-K, Gottsch ML, Lee KJ, Popa SM, Smith JT, Jakawich SK, Clifton DK, Steiner RA, Herbison AE (2005) Activation of gonadotropin-releasing hormone neurons by kisspeptin as a neuroendocrine switch for the onset of puberty. J Neurosci 25:1134911356. CrossRef Medline

Hrabovszky E, Steinhauser A, Barabás K, Shughrue PJ, Petersen SL, Merchenthaler I, Liposits Z (2001) Estrogen receptor-beta immunoreactivity in luteinizing hormone-releasing hormone neurons of the rat brain. Endocrinology 142:3261-3264. CrossRef Medline

Itri JN, Vosko AM, Schroeder A, Dragich JM, Michel S, Colwell CS (2010) Circadian regulation of a-type potassium currents in the suprachiasmatic nucleus. J Neurophysiol 103:632-640. CrossRef Medline

Jackson MB, Konnerth A, Augustine GJ (1991) Action potential broadening and frequency-dependent facilitation of calcium signals in pituitary nerve terminals. Proc Natl Acad Sci U S A 88:380384. Medline

Jacobs JM, Meyer T (1997) Control of action potential-induced $\mathrm{Ca}^{2+}$ signaling in the soma of hippocampal neurons by $\mathrm{Ca}^{2+}$ release from intracellular stores. J Neurosci 17:4129-4135. Medline

Karsch FJ, Cummins JT, Thomas GB, Clarke IJ (1987) Steroid feedback inhibition of pulsatile secretion of gonadotropin-releasing hormone in the ewe. Biol Reprod 36:1207-1218. Medline

Khaliq ZM, Bean BP (2010) Pacemaking in dopaminergic ventral tegmental area neurons: depolarizing drive from background and voltage-dependent sodium conductances. J Neurosci 30:74017413. CrossRef Medline

Kinoshita M, Tsukamura H, Adachi S, Matsui H, Uenoyama Y, Iwata K, Yamada S, Inoue K, Ohtaki T, Matsumoto H, Maeda K-I (2005) Involvement of central metastin in the regulation of preovulatory luteinizing hormone surge and estrous cyclicity in female rats. Endocrinology 146:4431-4436. CrossRef
Krahe R, Gabbiani F (2004) Burst firing in sensory systems. Nat Rev Neurosci 5:13-23. CrossRef Medline

Kriegsfeld LJ (2013) Circadian regulation of kisspeptin in female reproductive functioning. Adv Exp Med Biol 784:385-410. CrossRef Medline

Kuehl-Kovarik MC, Pouliot WA, Halterman GL, Handa RJ, Dudek FE, Partin KM (2002) Episodic bursting activity and response to excitatory amino acids in acutely dissociated gonadotropin-releasing hormone neurons genetically targeted with green fluorescent protein. J Neurosci 22:2313-2322. Medline

Kumar D, Candlish M, Periasamy V, Avcu N, Mayer C, Boehm U (2015) Specialized subpopulations of kisspeptin neurons communicate with $\mathrm{GnRH}$ neurons in female mice. Endocrinology 156:3238. CrossRef Medline

Lee JH, Gomora JC, Cribbs LL, Perez-Reyes E (1999) Nickel block of three cloned T-type calcium channels: low concentrations selectively block alpha1H. Biophys J 77:3034-3042. CrossRef Medline Lubbers LS, Hileman SM, Kuehl DE, Ferreira SA, Jackson GL (1998) Temporal effects of estradiol (E) on luteinizing hormone-releasing hormone (LHRH) and LH release in castrated male sheep. Domest Anim Endocrinol 15:511-524. Medline

Mayer C, Acosta-Martinez M, Dubois SL, Wolfe A, Radovick S, Boehm U, Levine JE (2010) Timing and completion of puberty in female mice depend on estrogen receptor alpha-signaling in kisspeptin neurons. Proc Natl Acad Sci U S A 107:22693-22698. CrossRef Medline

Moenter SM, Caraty A, Karsch FJ (1990) The estradiol-induced surge of gonadotropin-releasing hormone in the ewe. Endocrinology 127:1375-1384. CrossRef Medline

Moenter SM, Brand RC, Karsch FJ (1992) Dynamics of gonadotropin-releasing hormone $(\mathrm{GnRH})$ secretion during the $\mathrm{GnRH}$ surge: insights into the mechanism of $\mathrm{GnRH}$ surge induction. Endocrinology 130:2978-2984. CrossRef Medline

Molineux ML, Fernandez FR, Mehaffey WH, Turner RW (2005) A-type and T-type currents interact to produce a novel spike latencyvoltage relationship in cerebellar stellate cells. J Neurosci 25: 10863-10873. CrossRef Medline

Molineux ML, McRory JE, McKay BE, Hamid J, Mehaffey WH, Rehak R, Snutch TP, Zamponi GW, Turner RW (2006) Specific T-type calcium channel isoforms are associated with distinct burst phenotypes in deep cerebellar nuclear neurons. Proc Natl Acad Sci U S A 103:5555-5560. CrossRef Medline

Morissette M, Le Saux M, D'Astous M, Jourdain S, Al Sweidi S, Morin N, Estrada-Camarena E, Mendez P, Garcia-Segura LM, Di Paolo T (2008) Contribution of estrogen receptors alpha and beta to the effects of estradiol in the brain. J Steroid Biochem Mol Biol 108: 327-338. CrossRef Medline

Muschol M, Salzberg BM (2000) Dependence of transient and residual calcium dynamics on action-potential patterning during neuropeptide secretion. J Neurosci 20:6773-6780. Medline

Nelson MT, Joksovic PM, Su P, Kang H-W, Van Deusen A, Baumgart JP, David LS, Snutch TP, Barrett PQ, Lee J-H, Zorumski CF, Perez-Reyes E, Todorovic SM (2007) Molecular mechanisms of subtype-specific inhibition of neuronal T-type calcium channels by ascorbate. J Neurosci 27:12577-12583. CrossRef Medline

Oakley AE, Clifton DK, Steiner RA (2009) Kisspeptin signaling in the brain. Endocr Rev 30:713-743. CrossRef Medline

Paxinos G, Franklin K (2001) The mouse brain in stereotaxic coordinates, Ed 2. San Diego, CA: Elsevier Academic.

Perez-Reyes E (2003) Molecular physiology of low-voltage-activated t-type calcium channels. Physiol Rev 83:117-161. CrossRef Medline

Perreault P, Avoli M (1991) Physiology and pharmacology of epileptiform activity induced by 4-aminopyridine in rat hippocampal slices. J Neurophysiol 65:771-785. Medline

Pielecka-Fortuna J, Chu Z, Moenter SM (2008) Kisspeptin acts directly and indirectly to increase gonadotropin-releasing hormone neuron activity and its effects are modulated by estradiol. Endocrinology 149:1979-1986. CrossRef Medline 
Pielecka-Fortuna J, DeFazio RA, Moenter SM (2011) Voltage-gated potassium currents are targets of diurnal changes in estradiol feedback regulation and kisspeptin action on gonadotropinreleasing hormone neurons in mice. Biol Reprod 85:987-995. CrossRef Medline

Piet R, Boehm U, Herbison AE (2013) Estrous cycle plasticity in the hyperpolarization-activated current $I_{\mathrm{h}}$ is mediated by circulating 17-estradiol in preoptic area kisspeptin neurons. J Neurosci 33: 10828-10839. CrossRef Medline

Piet R, Fraissenon A, Boehm U, Herbison AE (2015) Estrogen permits vasopressin signaling in preoptic kisspeptin neurons in the female mouse. J Neurosci 35:6881-6892. CrossRef Medline

Pinilla L, Aguilar E, Dieguez C, Millar RP, Tena-Sempere M (2012) Kisspeptins and reproduction: physiological roles and regulatory mechanisms. Physiol Rev 92:1235-1316. CrossRef Medline

Prinz AA, Bucher D, Marder E (2004) Similar network activity from disparate circuit parameters. Nat Neurosci 7:1345-1352. CrossRef Medline

Puopolo M, Raviola E, Bean BP (2007) Roles of subthreshold calcium current and sodium current in spontaneous firing of mouse midbrain dopamine neurons. J Neurosci 27:645-656. CrossRef Medline

Robertson JL, Clifton DK, De La Iglesia HO, Steiner RA, Kauffman AS (2009) Circadian regulation of Kiss1 neurons: implications for timing the preovulatory gonadotropin-releasing hormone/luteinizing hormone surge. Endocrinology 150:3664-3671. CrossRef Medline

Ruka KA, Burger LL, Moenter SM (2013) Regulation of arcuate neurons coexpressing kisspeptin, neurokinin $\mathrm{B}$, and dynorphin by modulators of neurokinin 3 and $\kappa$-opioid receptors in adult male mice. Endocrinology 154:2761-2771. CrossRef Medline

Shim WS, Conaway M, Masamura S, Yue W, Wang JP, Kumar R, Santen RJ (2000) Estradiol hypersensitivity and mitogen-activated protein kinase expression in long-term estrogen deprived human breast cancer cells in vivo. Endocrinology 141:396-405. CrossRef

Smith JT, Cunningham MJ, Rissman EF, Clifton DK, Steiner RA. (2005) Regulation of Kiss1 gene expression in the brain of the female mouse. Endocrinology 146:3686-3692. CrossRef Medline

Smith JT, Popa SM, Clifton DK, Hoffman GE, Steiner RA (2006) Kiss1 neurons in the forebrain as central processors for generating the preovulatory luteinizing hormone surge. J Neurosci 26:6687-6694. CrossRef Medline

Suzuki S, Rogawski M a (1989) T-type calcium channels mediate the transition between tonic and phasic firing in thalamic neurons. Proc Natl Acad Sci U S A 86:7228-7232. Medline

Swensen AM, Bean BP (2005) Robustness of burst firing in dissociated Purkinje neurons with acute or long-term reductions in sodium conductance. J Neurosci 25:3509-3520. CrossRef Medline

Tadayonnejad R, Anderson D, Molineux ML, Mehaffey WH, Jayasuriya K, Turner RW (2010) Rebound discharge in deep cerebellar nuclear neurons in vitro. Cerebellum 9:352-374. CrossRef Medline

Talavera K, Nilius B (2006) Biophysics and structure-function relationship of T-type Ca2+ channels. Cell Calcium 40:97-114. CrossRef Medline

Underwood AJ (1997) Experiments in ecology. Cambridge, UK: Cambridge UP.

van den Pol AN (2012) Neuropeptide transmission in brain circuits. Neuron 76:98-115. CrossRef Medline

Vasudevan N, Pfaff DW (2008) Non-genomic actions of estrogens and their interaction with genomic actions in the brain. Front Neuroendocrinol 29:238-257. CrossRef Medline

Yip SH, Boehm U, Herbison AE, Campbell RE (2015) Conditional viral tract tracing delineates the projections of the distinct kisspeptin neuron populations to gonadotropin-releasing hormone $(\mathrm{GnRH})$ neurons in the mouse. Endocrinology 156:2582-2594. CrossRef Medline

Zhang C, Bosch MA, Rønnekleiv OK, Kelly MJ (2013a) Kisspeptin activation of TRPC4 channels in female $\mathrm{GnRH}$ neurons requires PIP2 depletion and cSrc kinase activation. Endocrinology 154: 2772-2783. CrossRef Medline

Zhang C, Tonsfeldt KJ, Qiu J, Bosch MA, Kobayashi K, Steiner RA, Kelly MJ, Rønnekleiv OK (2013b) Molecular mechanisms that drive estradiol-dependent burst firing of Kiss1 neurons in the rostral periventricular preoptic area. Am J Physiol Endocrinol Metab 305: E1384-E1397.

Zhang C, Bosch MA, Qiu J, Rønnekleiv OK, Kelly MJ (2015) $17 \beta-$ Estradiol increases persistent $\mathrm{Na}(+)$ current and excitability of AVPV/PeN Kiss1 neurons in female mice. Mol Endocrinol 29:518527. CrossRef Medline 